\title{
Point-of-Care C-Reactive Protein Testing to Reduce Antibiotic Prescribing for Respiratory Tract Infections in Primary Care: Systematic Review and Meta-Analysis of Randomised Controlled Trials
}

\author{
Nahara Anani Martínez-González ${ }^{1,2, *} \mathbb{\infty}$, Ellen Keizer ${ }^{1}$, Andreas Plate ${ }^{1}\left(\mathbb{D}\right.$, Samuel Coenen ${ }^{3,4}{ }^{\oplus}$, \\ Fabio Valeri ${ }^{1}$, Jan Yvan Jos Verbakel ${ }^{5,6}{ }^{\infty}$, Thomas Rosemann ${ }^{1}{ }^{\circledR}$, Stefan Neuner-Jehle ${ }^{1}$ and \\ Oliver Senn ${ }^{1}$ (D) \\ 1 Institute of Primary Care, University of Zurich and University Hospital of Zurich, Pestalozzistrasse 24, \\ CH-8091 Zurich, Switzerland; ellen.keizer@usz.ch (E.K.); andreas.plate@usz.ch (A.P.); \\ fabio.valeri@usz.ch (F.V.); thomas.rosemann@usz.ch (T.R.); stefan.neuner-jehle@usz.ch (S.N.-J.); \\ oliver.senn@usz.ch (O.S.) \\ 2 Department of Health Sciences and Medicine, University of Lucerne, Frohburgstrasse 3, PO Box 4466, \\ CH-6002 Lucerne, Switzerland \\ 3 Centre for General Practice, Department of Family Medicine \& Population Health (FAMPOP), \\ University of Antwerp-Campus Drie Eiken, Doornstraat 331, 2610 Antwerp (Wilrijk), Belgium; \\ samuel.coenen@uantwerpen.be \\ 4 Laboratory of Medical Microbiology, Vaccine \& Infectious Disease Institute (VAXINFECTIO), \\ University of Antwerp-Campus Drie Eiken, Universiteitsplein 1, 2610 Antwerp (Wilrijk), Belgium \\ 5 EPI-Centre, Department of Public Health and Primary Care, KU Leuven (University of Leuven), \\ Kapucijnenvoer 33, 3000 Leuven, Belgium; jan.verbakel@kuleuven.be \\ 6 Nuffield Department of Primary Care Health Sciences, NIHR Community Healthcare MIC, \\ University of Oxford, Radcliffe Primary Care Building, Radcliffe Observatory Quarter, Woodstock Road, \\ Oxford OX2 6GG, UK \\ * Correspondence: nahara.martinez@usz.ch
}

Received: 29 July 2020; Accepted: 12 September 2020; Published: 16 September 2020

\begin{abstract}
C-reactive protein (CRP) point-of-care testing (POCT) is increasingly being promoted to reduce diagnostic uncertainty and enhance antibiotic stewardship. In primary care, respiratory tract infections (RTIs) are the most common reason for inappropriate antibiotic prescribing, which is a major driver for antibiotic resistance. We systematically reviewed the available evidence on the impact of CRP-POCT on antibiotic prescribing for RTIs in primary care. Thirteen moderate to high-quality studies comprising 9844 participants met our inclusion criteria. Meta-analyses showed that CRP-POCT significantly reduced immediate antibiotic prescribing at the index consultation compared with usual care (RR $0.79,95 \%$ CI 0.70 to $0.90, p=0.0003, \mathrm{I}^{2}=76 \%$ ) but not during 28-day $(n=7)$ follow-up. The immediate effect was sustained at 12 months $(n=1)$. In children, CRP-POCT reduced antibiotic prescribing when CRP (cut-off) guidance was provided $(n=2)$. Meta-analyses showed significantly higher rates of re-consultation within 30 days $(n=8,1$ significant). Clinical recovery, resolution of symptoms, and hospital admissions were not significantly different between CRP-POCT and usual care. CRP-POCT can reduce immediate antibiotic prescribing for RTIs in primary care (number needed to $(\mathrm{NNT})$ for benefit $=8$ ) at the expense of increased re-consultations (NNT for harm $=27$ ). The increase in re-consultations and longer-term effects of CRP-POCT need further evaluation. Overall, the benefits of CRP-POCT outweigh the potential harms (NNTnet $=11$ ).
\end{abstract}

Keywords: antibiotic stewardship; antibiotic prescribing; antibiotic use; point-of-care testing; c-reactive protein; diagnostics; respiratory tract infection; primary care; systematic review; meta-analysis 


\section{Introduction}

Acute respiratory tract infections (RTIs) are among the most common reasons for patient encounters in primary care and for inappropriate antibiotic prescribing, which is a major driver for antibiotic resistance (ABR) [1-5]. RTIs are predominantly of viral aetiology and self-limiting in most otherwise healthy individuals. Evidence from systematic reviews and other studies shows that most patients suffering from acute RTIs, such as sore throat, acute sinusitis, pharyngitis, rhinosinusitis, otitis media, and acute bronchitis, do not benefit from antibiotic therapy [6-8]. International clinical practice guidelines consequently advise against routine treatment of uncomplicated RTIs with antibiotics [9]. The vast majority of patients with these infections, however, receive an antibiotic prescription for systemic use after seeking medical attention from their primary care physician $[4,10]$.

Inappropriate use of antibiotics is linked to the development of drug-resistant bacteria and increases the incidence of adverse events, re-consultations, and complications and subsequently increases healthcare costs [3,11-15]. Moreover, the rates of antibiotic prescribing have been directly associated with the rates of ABR at the individual, community, and national levels [3,4]. The reduction of antibiotic prescribing for acute RTIs could thus help to decrease ABR. If no effective actions are taken ABR could become the leading cause of death, surpassing cancer [16].

C-reactive protein (CRP) point-of-care test(-ing) (POCT) is one of the top strategies targeted at clinicians to reduce antibiotic prescribing, and it is increasingly being promoted to enhance antibiotic stewardship [17]. It has been demonstrated that uncertainty about the diagnosis of infection can lead to inappropriate antibiotic prescribing, overuse of resources, and disease complications [18-20]. With CRP as a biomarker of systematic inflammation, however, CRP-POCT enables clinicians to discern bacterial infections from other inflammatory disorders and helps them to identify the patients who benefit the most from antibiotics [21]. The robustness and accuracy of CRP-POCT compared with laboratory testing have been demonstrated by diagnostic studies [22]. CRP-POCT has also been integrated into some clinical guidelines as part of the assessment for RTIs to reduce diagnostic uncertainty and to aid prescribing decisions [23,24].

Two systematic reviews have suggested that CRP-POCT provided with prescribing guidance can reduce antibiotic prescribing for acute infections. One review focused on RTIs in primary care, but the results published six years ago were limited by a small number of studies of generally small samples that included mostly adults [25]. The second review with a broader scope included all acute infections presenting to ambulatory care [26]. We performed a systematic review to assess the evidence on the clinical effectiveness of CRP-POCT compared with usual care in reducing antibiotic prescribing for RTIs in primary care.

\section{Results}

\subsection{Identification of Studies}

Our searches identified 14,166 records. After full-text evaluation, 152 publications were relevant for POCT. After excluding 34 publications [27-60] (Supplementary Materials), 13 studies [61-73] reported across 22 publications [61-82] met the inclusion criteria for CRP-POCT. Of those, 11 were published in English, one in Norwegian and one was published in both English and Danish. Figure 1 shows the flow of study identification and selection. 


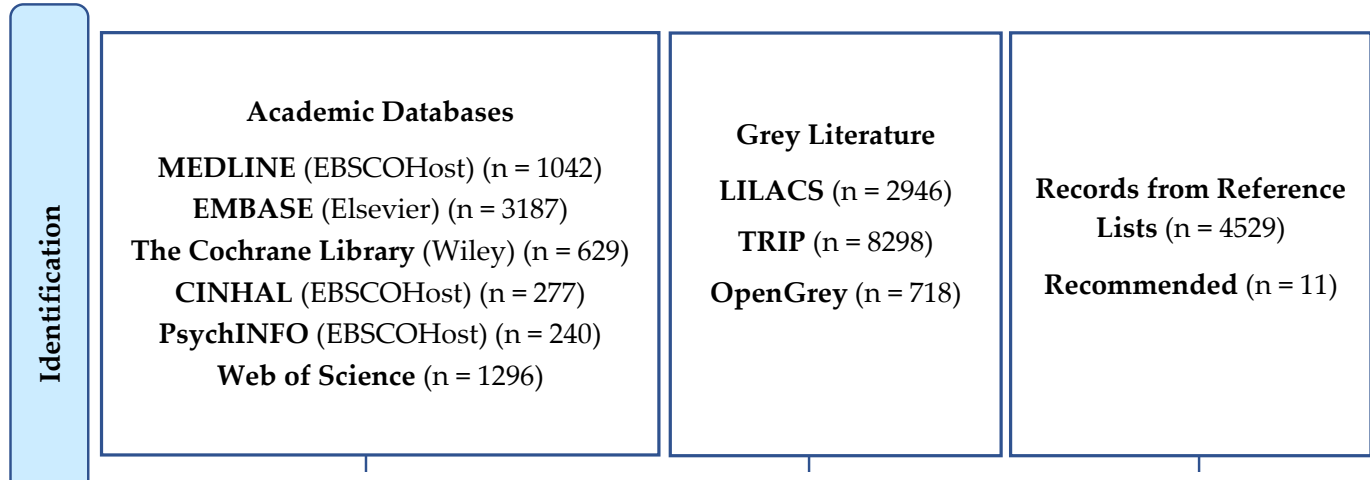

After deduplication within and/or across databases

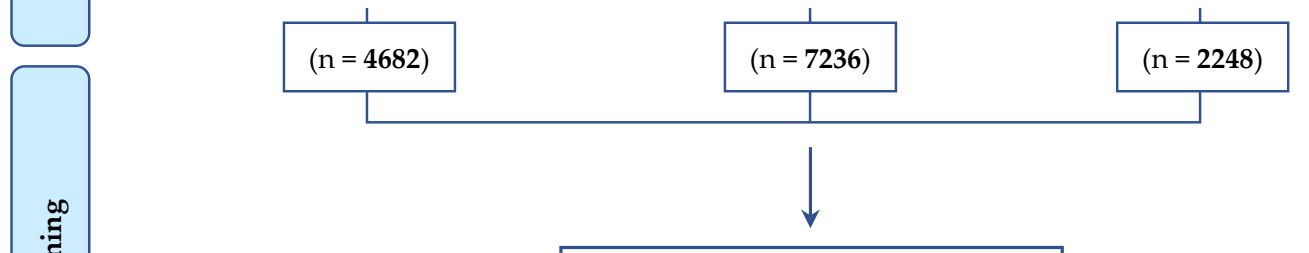

कूँ

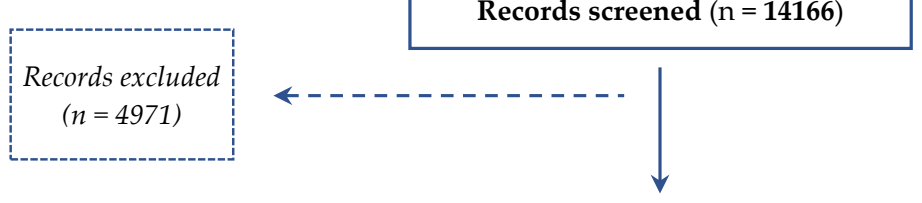



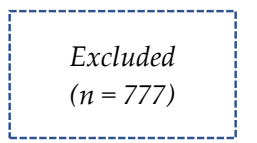

Selected for full-text evaluation $(\mathrm{n}=929)$

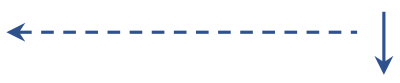

Full-Texts on POCT $(\mathrm{n}=152)$
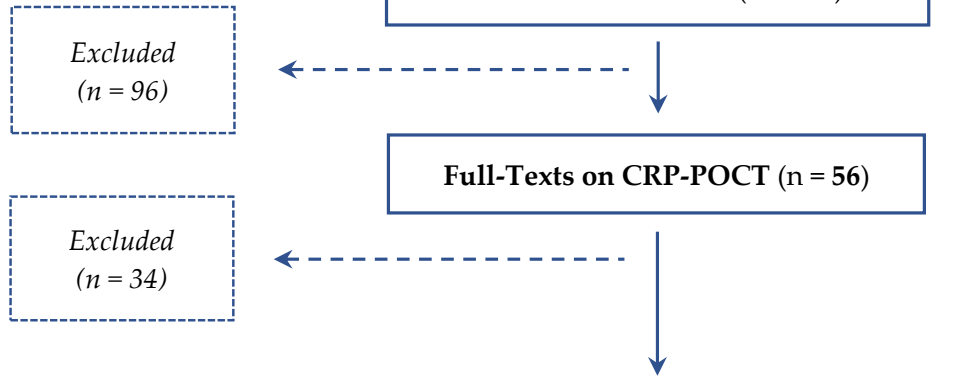

Included in systematic review and meta-analysis 13 RCTs published in 22 publications

Figure 1. Study identification and process for selection of studies included in the review.

\subsection{Study and Population Characteristics}

The studies were published from 1995 to 2019, with 10 studies in the last 10 years (2009-2019) (Table 1). Nine studies were conducted in eight European countries, mainly the Netherlands; four other studies were from Russia, the USA, Japan, and Vietnam. The studies were mostly carried out in the general practitioner's (GP) office $(n=7)$ and outpatient (primary care centres and hospital) services $(n=2)$. The type of RTI was anatomically defined as upper and/or lower in only six studies. RTI without specific signs or symptoms $(n=7)$ was the most common reason for encounter. 
Table 1. Characteristics of studies included in the review.

\begin{tabular}{|c|c|c|c|c|c|c|}
\hline $\begin{array}{l}\text { Study, Clinical Setting, } \\
\text { Facilities and Location }\end{array}$ & Population & $\begin{array}{l}\text { Interventionist and } \\
\text { Training in the } \\
\text { Intervention }\end{array}$ & $\begin{array}{l}\text { Intervention and } \\
\text { Number Randomised at } \\
\text { Baseline (N) }\end{array}$ & $\begin{array}{l}\text { Comparator and } \\
\text { Number Randomised at } \\
\text { Baseline (N) }\end{array}$ & $\begin{array}{l}\text { CRP-POCT Turnaround } \\
\text { Time and Manufacturer }\end{array}$ & $\begin{array}{l}\text { CRP (cut-off) Guidance for Interpretation } \\
\text { of CRP Levels }\end{array}$ \\
\hline $\begin{array}{l}\text { Schot, } 2018 \text { [61] } \\
\text { The Netherlands } \\
\text { Individual RCT } \\
28 \text { daytime general } \\
\text { practices and } 4 \mathrm{OOH} \\
\text { services across three } \\
\text { different regions in the } \\
\text { Netherlands }\end{array}$ & $\begin{array}{l}\text { Children with suspected } \\
\text { LRTI presenting with } \\
\text { acute cough of }<21 \text { days, } \\
\text { reported a fever of } \\
>38^{\circ} \mathrm{C} \text { for }<5 \text { days } \\
\text { Age, mean: } 4 \text { (SD } 2.1), \\
\text { range: } 3 \text { months to } \\
12 \text { years } \\
\text { Male, \%: } 51.5\end{array}$ & $\begin{array}{l}\text { GPs' training in the } \\
\text { intervention: } n . r .\end{array}$ & $\begin{array}{l}\text { GP CRP + clinical } \\
\text { assessment; } \mathrm{N}=136\end{array}$ & $\begin{array}{l}\text { Usual Care: treatment } \\
\text { decisions based on the } \\
\text { clinical assessment as } \\
\text { usual with no CRP; } \\
\mathrm{N}=165\end{array}$ & $\begin{array}{c}\leq 4 \mathrm{~min} \\
\text { Afinion, Alere } \\
\text { Technologies AS, Oslo, } \\
\text { Norway }\end{array}$ & $\begin{array}{l}\text { - } \mathrm{CRP}<10 \mathrm{mg} / \mathrm{L}=\text { Pneumonia less } \\
\text { likely, but should not be excluded if a } \\
\text { child is ill, or when the duration of } \\
\text { symptoms is }<6 \mathrm{~h} \\
\text { - } \mathrm{CRP}>100 \mathrm{mg} / \mathrm{L}=\text { Pneumonia much } \\
\text { more likely; however, such levels can } \\
\text { also be caused by viral infections } \\
\text { CRP } 10 \text { to } 100 \mathrm{mg} / \mathrm{L}=\text { Likelihood of } \\
\text { pneumonia increases with increasing } \\
\text { CRP levels }\end{array}$ \\
\hline $\begin{array}{l}\text { Verbakel, } 2016[62,74-76] \\
\text { Belgium } \\
\text { Cluster RCT } \\
78 \text { general practices } \\
\text { across Flanders }\end{array}$ & $\begin{array}{l}\text { Children with an acute } \\
\text { infection lasting a } \\
\text { maximum of } 5 \text { days at the } \\
\text { initial contact } \\
\text { Age, mean: } 3.87 \text { (SD } 4.0) \text {, } \\
\text { range: } 1 \text { month to } \\
16 \text { years } \\
\text { Male, } \%: 52.7\end{array}$ & $\begin{array}{l}\text { GPs trained to perform } \\
\text { the CRP test. Internal } \\
\text { quality control performed } \\
\text { according to the } \\
\text { manufacturer's } \\
\text { instructions }\end{array}$ & $\begin{array}{l}\text { GP CRP + clinical } \\
\text { assessment; } N=1730 \\
\text { infectious episodes in } \\
2773 \text { patients }\end{array}$ & $\begin{array}{l}\text { Usual Care: usual } \\
\text { practice + CRP only if at } \\
\text { clinical risk and } \\
\text { presenting at least one } \\
\text { symptom/sign of clinical } \\
\text { concern }{ }^{1} ; \mathrm{N}=1417 \\
\text { infectious episodes in } \\
2773 \text { patients }\end{array}$ & $\begin{array}{c}\leq 4 \mathrm{~min} \\
\text { Afinion AS100 Analyzer, } \\
\text { Alere, USA }\end{array}$ & $\begin{array}{l}\text { - } \quad \mathrm{CRP}<5 \mathrm{mg} / \mathrm{L}=\text { Low level = ruling } \\
\text { out antibiotics } \\
\text { - } \quad \mathrm{CRP} \geq 5 \mathrm{mg} / \mathrm{L}=\text { Elevated level }\end{array}$ \\
\hline $\begin{array}{l}\text { Van den Bruel, } 2016 \text { [63] } \\
\text { United Kingdom } \\
\text { (England) } \\
\text { Individual RCT } \\
2 \text { OOH services in } \\
\text { Oxfordshire }\end{array}$ & $\begin{array}{c}\text { Children with an acute } \\
\text { illness of } \leq 5 \text { days, fever } \\
\text { of } \geq 38^{\circ} \mathrm{C} \\
\text { Age, mean: } 2.8 \text { (SD 2.8), } \\
\text { range: } 1 \text { month to } \\
16 \text { years } \\
\text { Male, \%: } 51.5\end{array}$ & $\begin{array}{l}\text { Physicians' training in the } \\
\text { intervention: n.r. }\end{array}$ & $\begin{array}{l}\text { Physicians CRP + clinical } \\
\text { examination according to } \\
\text { usual care + clinical } \\
\text { guidance on } \\
\text { interpretation of CRP } \\
\text { levels; } \mathrm{N}=26\end{array}$ & $\begin{array}{l}\text { Usual Care: clinical } \\
\text { examination according to } \\
\text { usual care; } \mathrm{N}=28\end{array}$ & $\begin{array}{l}\text { 3-4 min } \\
\text { Afinion, Alere } \\
\text { Technologies }\end{array}$ & $\begin{array}{l}\text { - } \mathrm{CRP}<20 \mathrm{mg} / \mathrm{L}=\text { Serious infection is } \\
\text { less likely } \\
\text { - } \mathrm{CRP}>80 \mathrm{mg} / \mathrm{L}=\text { Serious infection is } \\
\text { more likely }\end{array}$ \\
\hline $\begin{array}{l}\text { Rebnord, } 2016 \text { [64,77] } \\
\text { Norway Individual RCT } \\
4 \text { OOH services and } \\
1 \text { paediatric walk-in } \\
\text { emergency hospital } \\
\text { facility in Bergen }\end{array}$ & $\begin{array}{l}\text { Children with fever or } \\
\text { any respiratory } \\
\text { symptoms } \\
\text { Age, mean: } 2.3 \text { (SD 1.8), } \\
\text { range: } 0 \text { to } 6 \text { years } \\
\text { Male, } \%: 55.7\end{array}$ & $\begin{array}{l}\text { NPs trained in the study } \\
\text { inclusion criteria and } \\
\text { examination procedures, } \\
\text { performed a clinical } \\
\text { examination and CRP } \\
\text { tests for all children } \\
\text { before consultation with } \\
\text { the doctor }\end{array}$ & $\begin{array}{l}\text { NP CRP pre-tested + NP } \\
\text { clinical examination } \\
\text { before consultation with } \\
\text { doctors + consultation } \\
\text { with paediatricians or } \\
\text { physicians with an } \\
\text { assessment of CRP } \\
\text { results; other tests were } \\
\text { also available; } N=138\end{array}$ & $\begin{array}{l}\text { Usual Care: NP clinical } \\
\text { examination with no CRP } \\
\text { assistance + clinical } \\
\text { assessment by } \\
\text { paediatricians or } \\
\text { physicians + CRP if } \\
\text { necessary, on individual } \\
\text { indication; other tests } \\
\text { were also available; } \\
\mathrm{N}=259\end{array}$ & $\begin{array}{l}\leq 2 \mathrm{~min} \\
\text { QuikRead Go, Orion } \\
\text { Diagnostica }\end{array}$ & n.r. \\
\hline
\end{tabular}


Table 1. Cont.

\begin{tabular}{|c|c|c|c|c|c|c|}
\hline $\begin{array}{l}\text { Study, Clinical Setting, } \\
\text { Facilities and Location }\end{array}$ & Population & $\begin{array}{l}\text { Interventionist and } \\
\text { Training in the } \\
\text { Intervention }\end{array}$ & $\begin{array}{l}\text { Intervention and } \\
\text { Number Randomised at } \\
\text { Baseline (N) }\end{array}$ & $\begin{array}{l}\text { Comparator and } \\
\text { Number Randomised at } \\
\text { Baseline (N) }\end{array}$ & $\begin{array}{l}\text { CRP-POCT Turnaround } \\
\text { Time and Manufacturer }\end{array}$ & $\begin{array}{l}\text { CRP (cut-off) Guidance for Interpretation } \\
\text { of CRP Levels }\end{array}$ \\
\hline \multirow{3}{*}{$\begin{array}{l}\text { Do, } 2016 \text { [65] } \\
\text { Vietnam Individual RCT } \\
10 \text { primary health-care } \\
\text { centres - northern } \\
\text { Vietnam (routine, urgent } \\
\text { care and hospital referral) } \\
\text { within a } 60 \mathrm{~km} \text { radius of } \\
\text { Hanoi. Rural sites: } \\
\text { outpatient clinics - } \\
\text { district general hospital } \\
\text { (Ba Vi hospital) } 60 \mathrm{~km} \\
\text { West Hanoi }\end{array}$} & \multirow{3}{*}{$\begin{array}{l}\text { Children and adults with } \\
\text { suspected non-severe } \\
\text { acute RTI, with at least } \\
\text { one focal and one } \\
\text { systemic sign or } \\
\text { symptom lasting for less } \\
\text { than } 2 \text { weeks } \\
\text { Age, mean: } 21.2 \text { (SD 23.8), } \\
\text { range: } 1 \text { to } 65 \text { years } \\
\text { Male, } \%: 39.9\end{array}$} & \multirow{3}{*}{$\begin{array}{l}\text { Physicians trained to use } \\
\text { specific CRP cut-offs with } \\
\text { initial workshop and } \\
\text { further training during } \\
\text { onsite implementation. } \\
\text { Training materials: oral } \\
\text { presentations and written } \\
\text { information leaflets for } \\
\text { doctors and health } \\
\text { centres; posters and desk } \\
\text { reminders with } \\
\text { recommended cut-off } \\
\text { values for specific age } \\
\text { groups }\end{array}$} & \multirow{3}{*}{$\begin{array}{l}\text { Physician CRP + } \\
\text { guidance based on CRP } \\
\text { cut-off values adapted for } \\
\text { use in children + GPs } \\
\text { advised to use their } \\
\text { clinical discretion for CRP } \\
\text { values between } \\
\text { thresholds, and could } \\
\text { potentially perform } \\
\text { further examinations at } \\
\text { their clinical discretion; } \\
\text { all patients received a } \\
\text { routine medical history } \\
\text { examination; } \mathrm{N}=1017\end{array}$} & \multirow{3}{*}{$\begin{array}{l}\text { Usual Care: routine } \\
\text { practice + use of local } \\
\text { treatment guidelines + } \\
\text { potential to perform } \\
\text { further examinations at } \\
\text { the discretion of the } \\
\text { treating physician; all } \\
\text { patients received a } \\
\text { routine medical history } \\
\text { examination; } \mathrm{N}=1019\end{array}$} & \multirow{3}{*}{$\begin{array}{c}\leq 3 \text { min } \\
\text { CRP single test kit } \\
\text { NycoCard II Reader, } \\
\text { Alere Technologies, } \\
\text { Norway }\end{array}$} & $\begin{array}{l}\text { General } \\
\text { - } \quad \mathrm{CRP} \leq 20 \mathrm{mg} / \mathrm{L}=\text { No antibiotics for } \\
\text { patients aged 6-65 years }\end{array}$ \\
\hline & & & & & & $\begin{array}{l}\text { Children } \\
\text { - } \quad \mathrm{CRP} \leq 10 \mathrm{mg} / \mathrm{L}=\text { No antibiotics for } \\
\text { patients aged } 1-5 \text { years } \\
\text { - } \mathrm{CRP}>20 \text { to }<50 \mathrm{mg} / \mathrm{L}=\text { No specific } \\
\text { recommendation but clinicians were } \\
\text { advised to use their clinical discretion } \\
\text { - } \mathrm{CRP} \geq 50 \mathrm{mg} / \mathrm{L}=\text { Should generally } \\
\text { receive antibiotics and hospital referral } \\
\text { should be considered }\end{array}$ \\
\hline & & & & & & $\begin{array}{l}\text { Adults } \\
\text { - } \quad \mathrm{CRP}>20 \text { to }<99 \mathrm{mg} / \mathrm{L}=\text { No specific } \\
\text { recommendation but clinicians were } \\
\text { advised to use their clinical discretion } \\
\text { - } \quad \mathrm{CRP} \geq 100 \mathrm{mg} / \mathrm{L}=\text { Should generally } \\
\text { receive antibiotics and hospital referral } \\
\text { should be considered }\end{array}$ \\
\hline $\begin{array}{l}\text { Andreeva, } 2014 \text { [66] } \\
\text { Russia } \\
\text { Cluster RCT } \\
18 \text { general practices: } \\
9 \text { Arkhangelsk region, } \\
9 \text { Murmansk region }\end{array}$ & $\begin{array}{c}\text { Adults with acute } \\
\text { cough/LRTI (acute } \\
\text { bronchitis, pneumonia, } \\
\text { infectious exacerbations } \\
\text { of COPD or asthma), } \\
\text { illness of fewer than } 28 \\
\text { days duration } \\
\text { Age, mean: } 50.8 \text { (SD n.r.), } \\
\text { range: } \geq 18 \text { years } \\
\text { Male, } \%: 27.4\end{array}$ & $\begin{array}{l}\text { GPs: two vocational } \\
\text { training sessions on CRP } \\
\text { test, theoretical and } \\
\text { practical information, } \\
\text { guidelines on the } \\
\text { interpretation of CRP, } \\
\text { a summary of the } \\
\text { literature on RTI and CRP } \\
\text { role, and paper cases of } \\
\text { patients with different } \\
\text { RTIs and different CRP } \\
\text { values were discussed }\end{array}$ & $\begin{array}{l}\text { GP CRP + guidance on } \\
\text { the interpretation of CRP } \\
\text { results +/- accessibility } \\
\text { and order of chest } \\
\text { radiography (for all } \\
\text { patients) and other } \\
\text { investigations (e.g., } \\
\text { a culture of sputum, } \\
\text { spirometry, } \\
\text { electrocardiogram) when } \\
\text { necessary; } N=8 \mathrm{GP} \\
\text { offices, } 101 \text { patients }\end{array}$ & $\begin{array}{l}\text { Usual Care: clinical } \\
\text { assessment with no CRP } \\
+/ \text { - chest radiography for } \\
\text { all patients and other } \\
\text { investigations when } \\
\text { necessary; choice of } \\
\text { antibiotic therapy } \\
\text { regimen left at the } \\
\text { discretion of physicians; } \\
\mathrm{N}=9 \text { GP offices, } \\
78 \text { patients }\end{array}$ & $\begin{array}{l}\quad \leq 5 \mathrm{~min} \\
\text { Afinion test system, } \\
\text { Axis-Shield, Norway }\end{array}$ & $\begin{array}{ll}\text { - } & \mathrm{CRP}<20 \mathrm{mg} / \mathrm{L}=\text { Antibiotics usually } \\
& \text { not needed } \\
\text { - } & \mathrm{CRP}>50 \mathrm{mg} / \mathrm{L}=\text { Antibiotics could be } \\
\text { indicated considering duration } \\
\text { of illness }\end{array}$ \\
\hline
\end{tabular}


Table 1. Cont.

\begin{tabular}{|c|c|c|c|c|c|}
\hline $\begin{array}{l}\text { Study, Clinical Setting, } \\
\text { Facilities and Location }\end{array}$ & Population & $\begin{array}{l}\text { Interventionist and } \\
\text { Training in the } \\
\text { Intervention }\end{array}$ & $\begin{array}{l}\text { Intervention and } \\
\text { Number Randomised at } \\
\text { Baseline (N) }\end{array}$ & $\begin{array}{l}\text { Comparator and } \\
\text { Number Randomised at } \\
\text { Baseline (N) }\end{array}$ & $\begin{array}{l}\text { CRP-POCT Turnaround } \\
\text { Time and Manufacturer }\end{array}$ \\
\hline $\begin{array}{l}\text { Little, } 2013[67,78,79] \\
\text { Spain, England, Wales, } \\
\text { Poland, Belgium, } \\
\text { The Netherlands } \\
\text { Individual RCT } \\
111 \text { GP practices from GP } \\
\text { networks of at least } 2 \\
\text { general practices in the } \\
\text { localities of study centres } \\
\text { of all } 6 \text { countries }\end{array}$ & $\begin{array}{l}\text { Adults with an acute } \\
\text { cough lasting up to } 28 \\
\text { days, or acute LRTI as the } \\
\text { main diagnosis (despite } \\
\text { cough not being the most } \\
\text { prominent symptom) and } \\
\text { acute URTI (sore throat, } \\
\text { otitis media, sinusitis, } \\
\text { influenza, and coryzal } \\
\text { illness) } \\
\text { Age, mean: } 26.4 \text { (SD 15.0), } \\
\text { range: } \geq 18 \text { years } \\
\text { Male, } \%: 36.7\end{array}$ & $\begin{array}{l}\text { GPs: a run-in period of } \\
\text { several weeks before data } \\
\text { collection to practise } \\
\text { using the device, internet } \\
\text { training on how to target } \\
\text { testing and how to } \\
\text { negotiate with the patient } \\
\text { about management } \\
\text { decisions }\end{array}$ & $\begin{array}{l}\text { GP CRP testing + } \\
\text { guidance on the } \\
\text { interpretation of CRP } \\
\text { testing and prescribing + } \\
\text { internet training on how } \\
\text { to target testing and how } \\
\text { to negotiate with the } \\
\text { patient about } \\
\text { management decisions }{ }^{2} \text {; } \\
\mathrm{N}=1062\end{array}$ & $\begin{array}{l}\text { 1) Usual Care: GPs } \\
\text { assessed and managed } \\
\text { patients according to the } \\
\text { practice's normal } \\
\text { procedures; } N=870\end{array}$ & $\begin{array}{c}\leq 5 \mathrm{~min} \\
\text { QuikRead CRP kits, } \\
\text { Orion Diagnostica, Espoo, } \\
\text { Finland }\end{array}$ \\
\hline
\end{tabular}

- $\quad \mathrm{CRP} \leq 20 \mathrm{mg} / \mathrm{L}=$ Withhold antibiotics self-limiting LRTI

- $\quad$ CRP 21 to $50 \mathrm{mg} / \mathrm{L}=$ Withhold patients have self-limiting LRTI; assess signs, symptoms, risk factors; CRP is important

- $\quad$ CRP 51 to $99 \mathrm{mg} / \mathrm{L}=$ Withhold antibiotics in the majority of cases and consider Delayed antibiotics in the minority of cases: assessment of signs, symptoms, risk factors; CRP is crucial

- $\quad \mathrm{CRP} \geq 100 \mathrm{mg} / \mathrm{L}=$ Prescribe antibiotics: severe infection

Low to Intermediate $(<30 \%)$ probability of Pneumonia $=$ abnormal signs OR abnormal chest examination:

\begin{tabular}{|c|c|c|c|c|}
\hline $\begin{array}{l}\text { Gonzales, } 2011 \text { [68] } \\
\text { United States } \\
\text { Individual RCT } \\
1 \text { ED supporting a 3-year } \\
\text { emergency medicine } \\
\text { residency program } \\
\text { located in a large, } \\
\text { Midwestern metropolitan } \\
\text { city in the United States }\end{array}$ & $\begin{array}{c}\text { Adults with a new cough } \\
\text { lasting } \leq 21 \text { days, at least } \\
\text { one other symptom of } \\
\text { acute RTI (fever, } \\
\text { sore throat, night sweats, } \\
\text { body aches, nasal or chest } \\
\text { congestion, shortness of } \\
\text { breath) } \\
\text { Age, mean: } 41.2 \text { (SD 12.5), } \\
\text { range: } \geq 18 \text { years } \\
\text { Male, } \%: 32.1\end{array}$ & $\begin{array}{l}\text { NPs performed CRP } \\
\text { testing; management } \\
\text { algorithms placed for } \\
\text { doctors in the medical } \\
\text { chart. ED visits and } \\
\text { house staff received } \\
\text { current evidence on CRP } \\
\text { levels as adjuncts in the } \\
\text { diagnosis of pneumonia } \\
\text { (or other } \\
\text { antibiotic-responsive } \\
\text { illnesses), a 1.5-h } \\
\text { educational seminar on } \\
\text { evidence-based } \\
\text { recommendations for } \\
\text { evaluation and treatment } \\
\text { of acute cough illness and } \\
\text { community-acquired } \\
\text { pneumonia for adults }\end{array}$ & $\begin{array}{l}\text { NP CRP + clinical } \\
\text { algorithm to guide } \\
\text { physicians on the } \\
\text { ordering of chest x-ray } \\
\text { and on antibiotic } \\
\text { treatment for adults with } \\
\text { acute cough illness and } \\
\text { community-acquired } \\
\text { pneumonia + activation } \\
\text { of GPs in using the } \\
\text { algorithm with a } \\
\text { statement ("Please } \\
\text { consider using this } \\
\text { algorithm in your clinical } \\
\text { care decisions, although it } \\
\text { should not substitute for } \\
\text { your clinical judgment"); } \\
\mathrm{N}=69\end{array}$ & $\begin{array}{l}\text { Usual Care: no CRP } \\
\text { testing + clinical } \\
\text { management algorithm to } \\
\text { guide recommendations } \\
\text { for a chest x-ray and } \\
\text { antibiotic treatment for } \\
\text { adults with acute cough } \\
\text { illness (based on a clinical } \\
\text { algorithm for predicting } \\
\text { pneumonia) + activation } \\
\text { of GPs in using the } \\
\text { algorithm with a } \\
\text { statement ("Please } \\
\text { consider using this } \\
\text { algorithm in your clinical } \\
\text { care decisions, although it } \\
\text { should not substitute for } \\
\text { your clinical judgment"); } \\
\mathrm{N}=62\end{array}$ \\
\hline
\end{tabular}

- $\quad \mathrm{CRP}<10 \mathrm{mg} / \mathrm{L}=$ Normal $=$ No

antibiotics and no chest $x$-ray

- $\quad$ CRP 10 to $99 \mathrm{mg} / \mathrm{L}=$ Intermediate:

Not helpful

- $\quad \mathrm{CRP} \geq 100 \mathrm{mg} / \mathrm{L}=$ High: Perform chest $\mathrm{x}$-ray:

Gonzales, 2011 [ Individual RCT 1 ED supporting a 3-y esigey medicine located in a large, city in the United Stap estion, shortness of
$\mathrm{N}=6$
$1 \mathrm{~min}$

QuikRead CRP, Orio Corporation, Orion Finland
- $\quad$ normal $x$-ray $=$ no antibiotics

$$
\text { _ } \quad \text { abnormal } x \text {-ray }=\text { antibiotics }
$$

High $(>30 \%)$ probability of

Pneumonia = abnormal signs WITH abnormal chest examination:

- $\quad \mathrm{CRP}<100 \mathrm{mg} / \mathrm{L}=$ Perform chest $\mathrm{x}$-ray:

- $\quad$ normal $x$-ray $=$ no antibiotic - abnormal $x$-ray $=$ antibiotics

- $\quad \mathrm{CRP} \geq 100 \mathrm{mg} / \mathrm{L}=$ Perform chest $\mathrm{x}$-ray:

- consider antibiotics regardless of 
Table 1. Cont.

\begin{tabular}{|c|c|c|c|c|c|c|}
\hline $\begin{array}{l}\text { Study, Clinical Setting, } \\
\text { Facilities and Location }\end{array}$ & Population & $\begin{array}{l}\text { Interventionist and } \\
\text { Training in the } \\
\text { Intervention }\end{array}$ & $\begin{array}{l}\text { Intervention and } \\
\text { Number Randomised at } \\
\text { Baseline (N) }\end{array}$ & $\begin{array}{l}\text { Comparator and } \\
\text { Number Randomised at } \\
\text { Baseline (N) }\end{array}$ & $\begin{array}{l}\text { CRP-POCT Turnaround } \\
\text { Time and Manufacturer }\end{array}$ & $\begin{array}{l}\text { CRP (cut-off) Guidance for Interpretation } \\
\text { of CRP Levels }\end{array}$ \\
\hline $\begin{array}{l}\text { Cals, } 2010 \text { [69] } \\
\text { The Netherlands } \\
\text { Individual RCT } \\
11 \text { family practice centres } \\
\text { in the south-eastern } \\
\text { Netherlands }\end{array}$ & $\begin{array}{c}\text { Adults with a current } \\
\text { episode of LRTI (cough } \\
\text { lasting }<4 \text { weeks with } \geq 1 \\
\text { of } 4 \text { focal signs and } \\
\text { symptoms and at least } \\
\text { one systemic sign and } \\
\text { symptom) or } \\
\text { Rhinosinusitis (episodes } \\
\text { lasting }<4 \text { weeks with at } \\
\text { least one symptom of } \\
\text { rhinorrhoea history and } \\
\text { blocked nose; and at least } \\
\text { one other symptom or } \\
\text { sign) } \\
\text { Age, mean: } 44.3 \text { (SD 13.8), } \\
\text { range: } \geq 18 \text { years } \\
\text { Male, \%: } 30.7\end{array}$ & $\begin{array}{l}\text { NPs received CRP device } \\
\text { demonstration, did not } \\
\text { communicate test result } \\
\text { to GP or patient until } \\
\text { after the study. GPs were } \\
\text { informed about the trial } \\
\text { procedure, received a } \\
\text { 30-min practice-based } \\
\text { seminar on the EB use of } \\
\text { CRP, stressing the } \\
\text { additional CRP value to } \\
\text { rule out serious infection } \\
\text { with emphasis on using } \\
\text { CRP together with } \\
\text { clinical findings, a 4-week } \\
\text { run-in period before } \\
\text { recruitment to get } \\
\text { familiar with CRP devices } \\
\text { and interpretation }\end{array}$ & $\begin{array}{l}\mathrm{NP} \mathrm{CRP} \mathrm{+/-GP} \mathrm{clinical} \\
\text { assessment and } \\
\text { management of antibiotic } \\
\text { therapy based on CRP } \\
\text { results + decision-making } \\
\text { on a management } \\
\text { strategy including } \\
\text { immediate, delayed or no } \\
\text { antibiotics; } \mathrm{N}=129\end{array}$ & $\begin{array}{l}\text { Usual Care: no CRP } \\
\text { testing + antibiotic } \\
\text { therapy based on clinical } \\
\text { assessment }+ \\
\text { decision-making on a } \\
\text { management strategy } \\
\text { including immediate, } \\
\text { delayed or no antibiotics; } \\
\mathrm{N}=129\end{array}$ & $\begin{array}{l}\leq 3 \mathrm{~min} \\
\text { QuikRead CRP analysers, } \\
\text { Orion Diagnostica, Espoo, } \\
\text { Finland }\end{array}$ & $\begin{array}{ll}\text { - } & \mathrm{CRP}<20 \mathrm{mg} / \mathrm{L}=\text { No antibiotics } \\
& \mathrm{CRP}>100 \\
\mathrm{mg} / \mathrm{L}=\mathrm{Immediate} \text { antibiotics } \\
\text { - } \quad \mathrm{CRP} 20 \text { to } 99 \mathrm{mg} / \mathrm{L}=\text { Delayed } \\
\text { prescription at physicians' discretion }\end{array}$ \\
\hline $\begin{array}{l}\text { Cals, } 2009[70,80,81] \\
\text { The Netherlands } \\
\text { Cluster RCT } \\
20 \text { general practices from } \\
\text { the South-Eastern part of } \\
\text { Noord-Brabant province } \\
\text { in the Netherlands } \\
\text { including urban and rural } \\
\text { areas; GP practices are } \\
\text { geographically spread } \\
\text { throughout this region }\end{array}$ & $\begin{array}{l}\text { Adults with suspected } \\
\text { LRTI, with a cough } \\
\text { lasting }<4 \text { weeks and } \\
\text { with one focal and one } \\
\text { systemic symptom } \\
\text { Age, mean: } 45.4 \text { (SD } 8.2 \text { ), } \\
\text { range: } \geq 18 \text { years } \\
\text { Male, } \%: 38.6\end{array}$ & $\begin{array}{l}\text { GPs received a 30-min } \\
\text { practice-based guideline } \\
\text { on how to use CRP, ruling } \\
\text { out a serious infection. } \\
\text { Practice nurses received } \\
\text { an introduction to } \\
\text { technical and practical } \\
\text { aspects. Practices } \\
\text { received an } \\
\text { 8-week-run-in period } \\
\text { before recruitment to } \\
\text { enable familiarisation } \\
\text { with CRP devices and } \\
\text { interpretation }\end{array}$ & $\begin{array}{l}\text { GP CRP + guidance on } \\
\text { the interpretation of } \\
\text { results based on CRP } \\
\text { cut-off values with an } \\
\text { emphasis on the } \\
\text { additional value of CRP } \\
\text { in ruling out serious } \\
\text { infection + familiarisation } \\
\text { with CRP devices and } \\
\text { interpretation of results; } \\
\mathrm{N}=110\end{array}$ & $\begin{array}{l}\text { (1) Usual Care: Dutch } \\
\text { guidelines-informed } \\
\text { clinical assessment for the } \\
\text { diagnosis and } \\
\text { management of acute } \\
\text { cough, and therapeutic } \\
\text { advice for LRTI; practices } \\
\text { were informed that they } \\
\text { would receive a CRP } \\
\text { device and/or } \\
\text { communication training } \\
\text { after the study period; } \\
\mathrm{N}=120 \\
\text { (2) ECST: motivational } \\
\text { interviewing built around } \\
11 \text { key tasks }{ }^{3} \text {; practices } \\
\text { were informed that they } \\
\text { would receive a CRP } \\
\text { device and/or the } \\
\text { communication training } \\
\text { after the study period; } \\
\mathrm{N}=84 \\
\text { (3) CRP + ECST; } \mathrm{N}=117\end{array}$ & $\begin{array}{l}\leq 3 \mathrm{~min} \\
\text { NycoCard II Reader, } \\
\text { Axis-Shield, Norway }\end{array}$ & $\begin{array}{l}\text { - } \mathrm{CRP}<20 \mathrm{mg} / \mathrm{L}=\text { Withhold antibiotics } \\
\text { in most patients with low values ( }<75 \% \\
\text { of patients with LRTI in primary care): } \\
\text { pneumonia extremely unlikely } \\
\text { CRP } 21 \text { to } 99 \mathrm{mg} / \mathrm{L}=\text { Delayed } \\
\text { antibiotics at discretion of physicians: } \\
\text { patients should be carefully assessed } \\
\text { based on the combination of medical } \\
\text { history, physical examination, and CRP } \\
\text { value: } \\
\text { - CRP } 20 \text { to } 50 \mathrm{mg} / \mathrm{L}=\text { pneumonia } \\
\text { very unlikely } \\
\text { CRP } 50 \text { to } 100=\text { clear infection, } \\
\text { most likely acute bronchitis, } \\
\text { possibly pneumonia: combine } \\
\text { with clinical findings; CRP is } \\
\text { very important } \\
\text { CRP }>100=\text { Immediate antibiotics: } \\
\text { severe infection, Pneumonia } \\
\text { more likely }\end{array}$ \\
\hline
\end{tabular}


Table 1. Cont

\begin{tabular}{|c|c|c|c|c|c|c|}
\hline $\begin{array}{l}\text { Study, Clinical Setting, } \\
\text { Facilities and Location }\end{array}$ & Population & $\begin{array}{l}\text { Interventionist and } \\
\text { Training in the } \\
\text { Intervention }\end{array}$ & $\begin{array}{l}\text { Intervention and } \\
\text { Number Randomised at } \\
\text { Baseline (N) }\end{array}$ & $\begin{array}{l}\text { Comparator and } \\
\text { Number Randomised at } \\
\text { Baseline (N) }\end{array}$ & $\begin{array}{l}\text { CRP-POCT Turnaround } \\
\text { Time and Manufacturer }\end{array}$ & $\begin{array}{l}\text { CRP (cut-off) Guidance for Interpretation } \\
\text { of CRP Levels }\end{array}$ \\
\hline $\begin{array}{l}\text { Takemura, 2005 [71] } \\
\text { Japan } \\
\text { Individual RCT } \\
1 \text { general/internal } \\
\text { medicine clinic of } \\
\text { Nishi-Ohmiya } \\
\text { regional/community } \\
\text { hospital }\end{array}$ & $\begin{array}{l}\text { Children and adults with } \\
\text { a clinically relevant fever } \\
\text { of }>37.5^{\circ} \mathrm{C} \\
\text { and symptoms suspected } \\
\text { of infection at the time of } \\
\text { or during the week before } \\
\text { an initial consultation } \\
\text { Age, mean: } 34.9 \text { (SD 15.4), } \\
\text { range: } 8 \text { to } 83 \\
\text { Male, } \%: 55.9\end{array}$ & $\begin{array}{l}\text { Physicians' training in the } \\
\text { intervention: n.r. }\end{array}$ & $\begin{array}{l}\text { Advanced testing group: } \\
\text { Physician CRP + WBC } \\
\text { testing before initial } \\
\text { consultation }+ \\
\text { information on CRP and } \\
\text { WBC normal reference } \\
\text { levels + if considered } \\
\text { necessary, potential to } \\
\text { perform urgent testing } \\
\text { after history taking and } \\
\text { physical examination }+ \\
\text { results of non-urgent } \\
\text { additional or subsequent } \\
\text { tests evaluated on } \\
\text { patient's next visit; } \\
\mathrm{N}=147\end{array}$ & $\begin{array}{l}\text { Usual Care: } \\
\text { non-advanced testing } \\
\text { group defined as } \\
\text { standard management } \\
\text { and treatment with no } \\
\text { CRP before initial } \\
\text { consultation }+ \\
\text { decision-making on } \\
\text { antibiotic management } \\
\text { and treatment based on } \\
\text { history taking and } \\
\text { physical examination + if } \\
\text { considered necessary, } \\
\text { potential to perform } \\
\text { urgent testing after } \\
\text { history taking and } \\
\text { physical examination; } \\
\mathrm{N}=154\end{array}$ & $\begin{array}{l}\text { CRP approx. 40-50 min; } \\
\text { WBC 10 min } \\
\text { CRP multichannel } \\
\text { analyser, model } \\
\text { TBA-30FR; Toshiba, } \\
\text { Saitama City, Japan }\end{array}$ & $\begin{array}{l}\text { - } \quad \mathrm{CRP} \leq 5 \mathrm{mg} / \mathrm{L}=\text { Normal } \\
\text { reference intervals }\end{array}$ \\
\hline $\begin{array}{l}\text { Diederichsen, } 2000 \\
\text { [72,82] } \\
\text { Denmark } \\
\text { Individual RCT } \\
35 \text { General practices in } \\
\text { the County of Funen in } \\
\text { Denmark }\end{array}$ & $\begin{array}{c}\text { Children and adults with } \\
\text { respiratory infections } \\
\text { Age, mean: } 41 \text { (SD 14.2), } \\
\text { range: median } 37 \text { (range: } \\
0 \text { to } 90 \text { ) } \\
\text { Male, \%: } 42.8\end{array}$ & $\begin{array}{l}\text { GPs discussed, before the } \\
\text { start of the study, the trial } \\
\text { procedure with the } \\
\text { project leader and a } \\
\text { product specialist from } \\
\text { Nycomed; a supervised } \\
\text { test trial was carried out }\end{array}$ & $\begin{array}{l}\text { GP CRP + clinical } \\
\text { assessment to guide } \\
\text { antibiotics prescribing + } \\
\text { information on the } \\
\text { normal levels of CRP for } \\
\text { antibiotic prescribing but } \\
\text { no strict guidelines were } \\
\text { given; } \mathrm{N}=414\end{array}$ & $\begin{array}{l}\text { Usual Care: clinical } \\
\text { assessment only; } \mathrm{N}=398\end{array}$ & $\begin{array}{c}\leq 3 \mathrm{~min} \\
\text { NycoCard CRP Reader, } \\
\text { Nycomed, Alere } \\
\text { Technologies, Afinion, } \\
\text { Norway }\end{array}$ & $\begin{array}{l}\text { - } \quad \mathrm{CRP}<10 \mathrm{mg} / \mathrm{L}=\text { Normal } \\
\text { - } \mathrm{CRP}<10 \mathrm{mg} / \mathrm{L}=\text { Seldom the result of } \\
\text { bacterial infection } \\
\text { - } \mathrm{CRP}<50 \mathrm{mg} / \mathrm{L}=\text { Seldom the result of } \\
\text { bacterial infection }\end{array}$ \\
\hline
\end{tabular}


Table 1. Cont.

\begin{tabular}{|c|c|c|c|c|c|c|}
\hline $\begin{array}{l}\text { Study, Clinical Setting, } \\
\text { Facilities and Location }\end{array}$ & Population & $\begin{array}{l}\text { Interventionist and } \\
\text { Training in the } \\
\text { Intervention }\end{array}$ & $\begin{array}{l}\text { Intervention and } \\
\text { Number Randomised at } \\
\text { Baseline (N) }\end{array}$ & $\begin{array}{l}\text { Comparator and } \\
\text { Number Randomised at } \\
\text { Baseline (N) }\end{array}$ & $\begin{array}{l}\text { CRP-POCT Turnaround } \\
\text { Time and Manufacturer }\end{array}$ & $\begin{array}{l}\text { CRP (cut-off) Guidance for Interpretatio } \\
\text { of CRP Levels }\end{array}$ \\
\hline $\begin{array}{l}\text { Melbye, } 1995 \text { [73] } \\
\text { Norway } \\
\text { Individual RCT } \\
10 \text { General practices in } \\
\text { Northern Norway }\end{array}$ & $\begin{array}{l}\text { Adults with signs of } \\
\text { pneumonia, bronchitis } \\
\text { and asthma, } \\
\text { who presented with } \\
\text { symptoms of coughing or } \\
\text { heavy breathing, or who } \\
\text { had chest pain that was } \\
\text { aggravated by coughing } \\
\text { or deep inspiration } \\
\text { Age, mean: } 49.25 \text { (SD } \\
\text { 11.6), range: } \geq 18 \text { years } \\
\text { Male, } \%: 36.9\end{array}$ & $\begin{array}{l}\text { GPs' training in the } \\
\text { intervention: n.r. }\end{array}$ & $\begin{array}{l}\text { GP CRP + doctors' } \\
\text { preliminary decision on } \\
\text { antibiotic treatment }+ \\
\text { guide on antibiotic } \\
\text { prescribing based on the } \\
\text { duration of illness } \\
\text { following recommended } \\
\text { CRP cut-off values (if a } \\
\text { preliminary decision } \\
\text { needed to change in light } \\
\text { of the CRP results); } \\
\mathrm{N}=108\end{array}$ & Usual Care, $\mathrm{N}=131$ & $\begin{array}{c}\leq 3 \mathrm{~min} \\
\text { NycoCard CRP Reader, } \\
\text { Nycomed, Alere } \\
\text { Technologies, Afinion, } \\
\text { Norway }\end{array}$ & $\begin{array}{l}\text { Disease duration } 0-24 \mathrm{~h} \\
\text { - } \quad \mathrm{CRP}<50 \mathrm{mg} / \mathrm{L}=\text { No change in } \\
\text { clinical decision } \\
\text { - } \quad \mathrm{CRP} \geq 50 \mathrm{mg} / \mathrm{L}=\text { Antibiotics } \\
\text { Disease duration } 1-6 \text { days } \\
\text { - } \quad \mathrm{CRP}<11 \mathrm{mg} / \mathrm{L}=\text { No } \\
\text { antibiotic prescribing } \\
\text { - } \quad \mathrm{CRP} 11-49 \mathrm{mg} / \mathrm{L}=\text { No change in } \\
\text { clinical decision } \\
\text { - } \quad \mathrm{CRP} \geq 50 \mathrm{mg} / \mathrm{L}=\text { Antibiotics } \\
\text { Disease duration } \geq 7 \text { days } \\
\text { - } \quad \mathrm{CRP}<11 \mathrm{mg} / \mathrm{L}=\text { No } \\
\text { antibiotic prescribing } \\
\text { - } \quad \mathrm{CRP} 11-24 \mathrm{mg} / \mathrm{L}=\text { No change in } \\
\text { - clinical decision } \\
\text { - } \mathrm{CRP} \geq 25 \mathrm{mg} / \mathrm{L}=\text { Antibiotics }\end{array}$ \\
\hline
\end{tabular}

Note. OOH, Out-Of-Hours care services; ED, Emergency Department services; SD, standard deviation; CRP, C-Reactive Protein; ECST, Enhanced Communication Skills Training; GP, General Practice or General Practitioner; NP, nurse or Nurse Practitioner; RTI, Respiratory Tract Infection; URTI, Upper Respiratory Tract Infection; LRTI, Lower Respiratory Tract Infection; COPD, Chronic Obstructive Pulmonary Disease; EB, Evidence-Based; n.r., not reported. ${ }^{1}$ Clinical risk was assessed with a validated clinical decision rule during clinical assessment; in a clinical risk group, CRP was dependent on the presence of at least one of the following clinical features: breathlessness, a body temperature of at least $40{ }^{\circ} \mathrm{C}$, diarrhoea in children 12-30 months of age, and clinician concern. ${ }^{2}$ Training in how to target testing in cases of clinical uncertainty consisted of e.g., patients with abnormal auscultation, fever dyspnoea. ${ }^{3}$ Motivational interviewing was built around 11 key aspects including, for example, exploring patients' fears and expectations, asking patients' opinion on $\mathrm{AB}$, and outlining the natural duration of cough in LRTI. 
The 13 studies comprised a total of 9844 randomised patients (Table 1); nine individually randomised 4529 patients to intervention groups [61,63-65,68,69,71-73], and four randomised 226 sites and/or 173 physicians with 5315 patients $[62,66,67,70]$. Six studies included adult patients only [66-70,73], four included children only [61-64], two included both adults and children [65,72], and one did not distinguish age groups [71]. Participants had a mean age of 26.4 (SD 15.0) (range: 0-90) years, and $43.9 \%$ were male. The ethnicity of patients was reported in only one study as follows: black (46\%), white (25\%), or other (29\%) [68]. Physician characteristics were reported in two studies [70,71]: they were 29-53 years old; had 5-29 years of experience; and in one study, 60\% were male [70].

\subsection{Intervention Characteristics}

CRP-POCT was performed by physicians [61-63,65-67,70-73] or nurses [64,68,69] (Table 1). Nine studies reported training in the intervention, which consisted of instructions on CRP devices, guidelines for the use of CRP, and/or management of RTIs [62,64-70,72]. In 11 studies, clinicians also received guidance or information for the interpretation of CRP results in terms of disease severity, antibiotic prescribing, or both. Only eight of these additionally provided specific CRP cut-off guidance to prescribe or to withhold antibiotics [62,65-70,73]. Studies used four types of CRP quantitative devices that comprised test kits and analysers, including NycoCard (II) CRP readers, QuickRead CRP kits, Afinion CRP, or CRP multichannel analyser. All studies compared CRP-POCT with a control intervention consisting of usual care. One study used a $2 \times 2$ factorial design and combined intervention groups, including the effect of enhanced communication skills training (CST), to both CRP-POCT and usual care [70]. Usual care was described as a clinical assessment as usual with CRP not tested $[61,63,64,72,73]$ or as routine practice according to normal procedures with/out access to other investigations [65,68-71,78]. However, CRP-POCT could have also been performed if patients in the usual care group were at clinical risk or if the results of physical examinations suggested it to be necessary $[62,66]$.

\subsection{Methodological Quality and Risk of Bias in the Methods of Included Studies}

All studies reported the participants' inclusion criteria and only ten reported the exclusion criteria (Table 2). While most studies (86\%) measured the success of interventions by definition of a primary outcome, a majority (64\%) also defined secondary outcomes. Most studies (93\%) reported sample size calculation and power. Four studies were funded, partly funded, or the reagents were provided by the manufacturers of the CRP-POCT devices $[61,65,69,73]$.

Domains of internal validity mostly showed a low or unclear risk of bias (Table 2 and Supplementary Materials). Most (79\%) studies adequately randomised participants, but it was often (64\%) unclear how allocation concealment was ensured in the randomisation process. As expected, considering the focus of our systematic review on clinical effectiveness, all studies were at high risk of performance bias as blinding of clinicians and patients to group allocation was not possible. Delivery of the intervention was dependent on both a patient POCT procedure and knowing the results of CRP to treat patients. Most studies adequately performed blinding of outcome assessors for both the primary (64\%) and secondary (57\%) outcomes, although only five reported the outcome assessors $[65,68,70,73,80]$. In all studies, primary outcome data were complete and had an acceptable level of attrition $(\leq 20 \%)$. The length of follow-up was the same for all groups in each study (range: 0 days to 3.5 years). 
Table 2. Methodological features and risk of bias in the included studies.

\begin{tabular}{|c|c|c|c|c|c|c|c|c|c|c|c|c|c|c|c|c|c|}
\hline $\begin{array}{l}\text { Study (First Author, } \\
\text { Publication Year) }\end{array}$ & 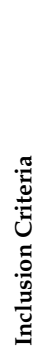 & 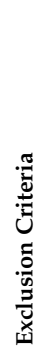 & 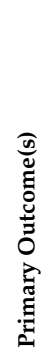 & 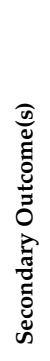 & 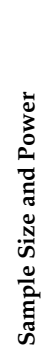 & 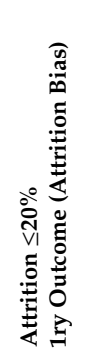 & 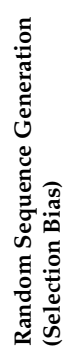 & 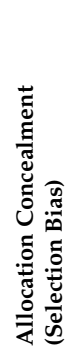 & 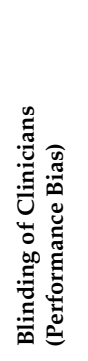 & 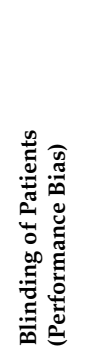 & 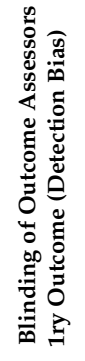 & 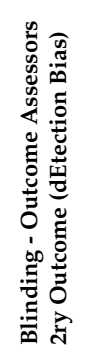 & 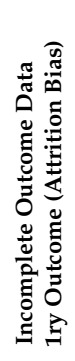 & 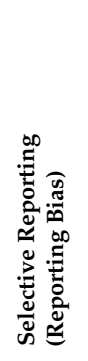 & 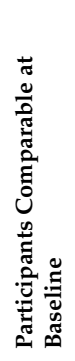 & 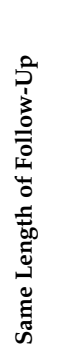 & Source of Funding \\
\hline $\begin{array}{l}\text { Schot, } 2018 \text { [61] } \\
\text { The Netherlands } \\
\text { Individual RCT }\end{array}$ & $\sqrt{ }$ & $\sqrt{ }$ & $\sqrt{ }$ & $\sqrt{ }$ & $\sqrt{ }$ & $\sqrt{ }$ & $\bullet$ & ○ & $\bullet$ & $\bullet$ & - & - & - & $\bullet$ & $\bullet$ & - & $\begin{array}{c}\text { Netherlands Organization } \\
\text { for HRD; Alere Technologies } \\
\text { AS; SALTRO \& Star Medical } \\
\text { Diagnostic Centre }\end{array}$ \\
\hline $\begin{array}{l}\text { Verbakel, } 2016 \text { [62,74-76] } \\
\text { Belgium } \\
\text { Cluster RCT }\end{array}$ & $\sqrt{ }$ & $\sqrt{ }$ & $\sqrt{ }$ & $\sqrt{ }$ & $\sqrt{ }$ & $\sqrt{ }$ & - & $\bullet$ & $\bullet$ & $\bullet$ & - & • & $\bullet$ & $\bullet$ & $\bullet$ & $\bullet$ & $\begin{array}{c}\text { NIHDI, Research } \\
\text { Foundation Flanders, } \\
\text { NIHR Diagnostic Evidence } \\
\text { Co-operative Oxford } \\
\end{array}$ \\
\hline $\begin{array}{l}\text { Van den Bruel, } 2016 \text { [63] } \\
\text { United Kingdom (England) } \\
\text { Individual RCT }\end{array}$ & $\sqrt{ }$ & $\sqrt{ }$ & $\sqrt{ }$ & $\sqrt{ }$ & $\sqrt{ }$ & $\sqrt{ }$ & $\bullet$ & $\bullet$ & $\bullet$ & $\bullet$ & - & $\bullet$ & $\bullet$ & 0 & - & $\bullet$ & $\begin{array}{l}\text { National School for Primary } \\
\text { Care Research }\end{array}$ \\
\hline $\begin{array}{l}\text { Rebnord, } 2016[64,77] \\
\text { Norway } \\
\text { Individual RCT }\end{array}$ & $\sqrt{ }$ & & $\sqrt{ }$ & $\sqrt{ }$ & $\sqrt{ }$ & $\sqrt{ }$ & - & ○ & $\bullet$ & $\bullet$ & - & ○ & - & $\bullet$ & - & ○ & Norwegian Research Fund \\
\hline $\begin{array}{l}\text { Do, } 2016 \text { [65] } \\
\text { Vietnam } \\
\text { Individual RCT }\end{array}$ & $\sqrt{ }$ & $\sqrt{ }$ & $\sqrt{ }$ & $\sqrt{ }$ & $\sqrt{ }$ & $\sqrt{ }$ & - & - & $\bullet$ & $\bullet$ & - & - & - & $\bullet$ & - & $\bullet$ & $\begin{array}{c}\text { Welcome Trust UK and } \\
\text { Global Antibiotic Resistance } \\
\text { Partnership; Alere } \\
\text { Technologies }\end{array}$ \\
\hline $\begin{array}{l}\text { Andreeva, } 2014 \text { [66] } \\
\text { Russia } \\
\text { Cluster RCT }\end{array}$ & $\sqrt{ }$ & $\sqrt{ }$ & $\sqrt{ }$ & $\sqrt{ }$ & $\sqrt{ }$ & $\sqrt{ }$ & $\bullet$ & - & 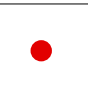 & $\bullet$ & - & - & $\bullet$ & ○ & $\bullet$ & $\bullet$ & Not reported \\
\hline $\begin{array}{l}\text { Little, } 2013[67,78,79] \\
\text { Spain, England, Wales, Poland, } \\
\text { Belgium, The Netherlands } \\
\text { Cluster RCT }\end{array}$ & $\sqrt{ }$ & $\sqrt{ }$ & $\sqrt{ }$ & $\sqrt{ }$ & $\sqrt{ }$ & $\sqrt{ }$ & $\bullet$ & 0 & $\bullet$ & $\bullet$ & - & $\bullet$ & $\bullet$ & $\bullet$ & $\bullet$ & $\bullet$ & $\begin{array}{c}\text { European Commission } \\
\text { Framework Programme, } \\
\text { NIHR, Research Foundation } \\
\text { Flanders }\end{array}$ \\
\hline
\end{tabular}


Table 2. Cont.

\begin{tabular}{|c|c|c|c|c|c|c|c|c|c|c|c|c|c|c|c|c|c|}
\hline $\begin{array}{l}\text { Study (First Author, } \\
\text { Publication Year) }\end{array}$ & 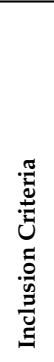 & 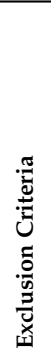 & 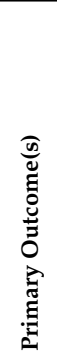 & 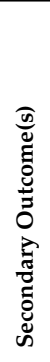 & 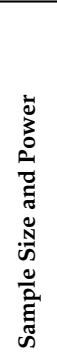 & 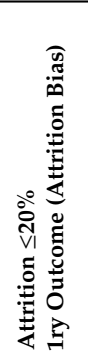 & 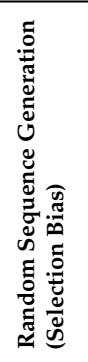 & 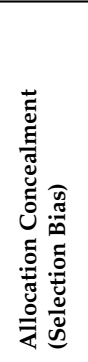 & 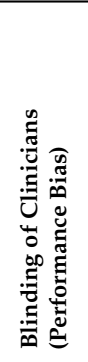 & 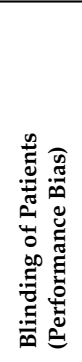 & 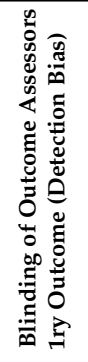 & 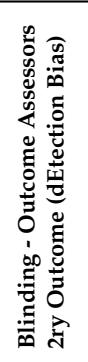 & 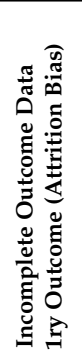 & 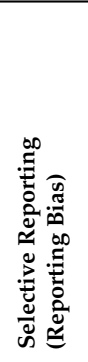 & 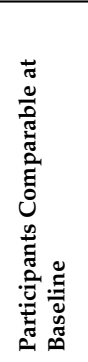 & 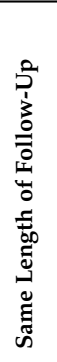 & Source of Funding \\
\hline $\begin{array}{l}\text { Gonzales, } 2011 \text { [68] } \\
\text { United States } \\
\text { Individual RCT }\end{array}$ & $\sqrt{ }$ & $\sqrt{ }$ & $\sqrt{ }$ & $\sqrt{ }$ & $\sqrt{ }$ & $\sqrt{ }$ & • & ○ & • & 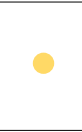 & 0 & 0 & $\bullet$ & - & • & - & $\begin{array}{c}\text { TRIP initiative and agency } \\
\text { for HRQ, HSRD Service of } \\
\text { the Department of Veterans } \\
\text { Affairs }\end{array}$ \\
\hline $\begin{array}{l}\text { Cals, } 2010[69] \\
\text { The Netherlands } \\
\text { Individual RCT }\end{array}$ & $\sqrt{ }$ & $\sqrt{ }$ & $\sqrt{ }$ & $\sqrt{ }$ & $\sqrt{ }$ & $\sqrt{ }$ & - & • & • & $\bullet$ & $\bullet$ & $\bullet$ & • & • & - & - & $\begin{array}{l}\text { Orion Diagnostica Espoo } \\
\text { Finland }\end{array}$ \\
\hline $\begin{array}{l}\text { Cals, } 2009[70,80,81] \\
\text { The Netherlands } \\
\text { Cluster RCT }\end{array}$ & $\sqrt{ }$ & $\sqrt{ }$ & $\sqrt{ }$ & $\sqrt{ }$ & $\sqrt{ }$ & $\sqrt{ }$ & • & 0 & • & $\bullet$ & - & $\bullet$ & - & - & • & 0 & $\begin{array}{l}\text { Netherlands Organisation } \\
\text { for HRD, Wales Office for } \\
\text { R\&D, NIHSC funded the } \\
\text { South East Wales Trial Unit }\end{array}$ \\
\hline $\begin{array}{l}\text { Takemura, } 2005 \text { [71] } \\
\text { Japan } \\
\text { Individual RCT }\end{array}$ & $\sqrt{ }$ & & & & & $\sqrt{ }$ & 0 & 0 & • & $\bullet$ & 0 & 0 & - & • & • & - & $\begin{array}{l}\text { International Clinical } \\
\text { Pathology Centre Tokyo }\end{array}$ \\
\hline $\begin{array}{l}\text { Diederichsen, } 2000[72,82] \\
\text { Denmark } \\
\text { Individual RCT }\end{array}$ & $\sqrt{ }$ & $\sqrt{ }$ & & & $\sqrt{ }$ & $\sqrt{ }$ & • & ○ & 0 & 0 & 0 & 0 & • & 0 & $\bullet$ & 0 & Not reported \\
\hline $\begin{array}{l}\text { Melbye, } 1995 \text { [73] } \\
\text { Norway } \\
\text { Individual RCT }\end{array}$ & $\sqrt{ }$ & $\sqrt{ }$ & $\sqrt{ }$ & & $\sqrt{ }$ & $\sqrt{ }$ & 0 & 0 & $\bullet$ & $\bullet$ & $\bullet$ & $\bullet$ & $\bullet$ & 0 & • & $\bullet$ & $\begin{array}{c}\text { Norwegian Research } \\
\text { Academy and Nycomed } \\
\text { Pharma }\end{array}$ \\
\hline
\end{tabular}

Note. Green = adequate; Yellow = unclear; Red = not adequate. NIHDI, National Institute for Health and Disability Insurance; NIHR, National Institute for Health and Research; TRIP,

Translating Research into Practice initiative; HRQ, Healthcare Research and Quality; HSRD, Health Services Research and Development; R\&D, Research and Development; NIHSC,

National Institute for Health and Social Care. 


\subsection{Effectiveness of the Use of CRP-POCT on (patient) Outcomes}

All 13 studies reported on the primary outcome of rates of antibiotic prescribing. Secondary outcomes were variably reported across studies, limiting the ability to conduct meta-analyses in some cases. The Supplementary Materials show the individual effect estimates not represented in forest plots and all additional figures from meta-analyses.

\subsubsection{Primary Outcomes}

Antibiotic Prescribing Rate at the Index Consultation

Meta-analysis of all 13 studies demonstrated significantly lower antibiotic prescribing in the CRP-POCT group compared with the usual care group (38.2\% vs. $51.4 \%$ : RR $0.79,95 \%$ CI 0.70 to 0.90 , $p=0.0003)$ (Figure 2). Between-study heterogeneity was considerable $\left(I^{2}=76 \%\right)$.

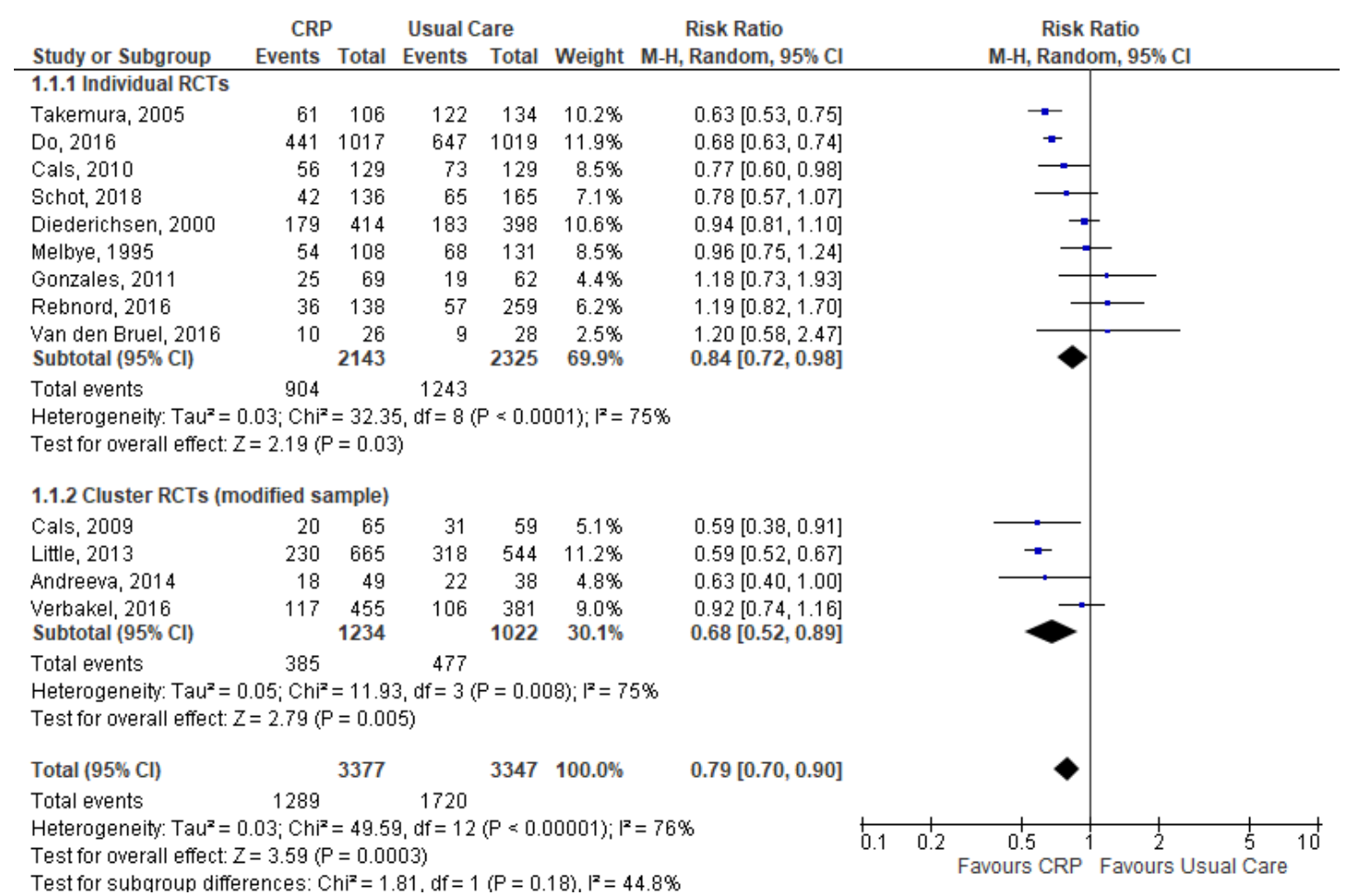

Figure 2. Comparison: CRP-POCT versus usual care. Overall antibiotic prescribing at index consultations. CRP, C-Reactive Protein Point Of Care Test; RCTs, Randomised Controlled Trials; $\mathrm{M}-\mathrm{H}$, Mantel-Haenszel; CI, Confidence Interval; $\mathrm{df}$, degrees of freedom; $\mathrm{I}^{2}$, heterogeneity between trials.

Subgroup Analyses of the Antibiotic Prescribing Rate at the Index Consultation

Subgroup analysis by type of RTI showed significantly lower antibiotic prescribing in the CRP-POCT group for URTI and for LRTI (URTI $(n=2), 32.3 \%$ vs. $49.4 \%$ : RR $0.67,95 \%$ CI 0.54 to 0.82 , $p=0.0002, \mathrm{I}^{2}=0 \%$; LRTI $(n=6), 37.1 \%$ vs. $55.2 \%$ : RR $0.72,95 \% \mathrm{CI} 0.58$ to $\left.0.88, p=0.002, \mathrm{I}^{2}=66 \%\right)$ (Figure 3). The pooled estimate showed no significant differences between groups from seven studies with undefined RTI, e.g., signs and symptoms of infection (Supplementary Materials). 


\begin{tabular}{|c|c|c|c|c|c|c|c|c|}
\hline \multirow{2}{*}{$\frac{\text { Study or Subgroup }}{\text { 2.1.1 Individual RCTs }}$} & \multicolumn{2}{|c|}{ CRP } & \multicolumn{2}{|c|}{ Usual Care } & \multirow{2}{*}{ Weight } & \multirow{2}{*}{$\begin{array}{c}\text { Risk Ratio } \\
\text { M-H, Random, } 95 \% \mathrm{Cl}\end{array}$} & \multicolumn{2}{|c|}{$\begin{array}{c}\text { Risk Ratio } \\
\text { M-H, Random, } 95 \% \mathrm{Cl}\end{array}$} \\
\hline & & & & & & & & \\
\hline $\begin{array}{l}\text { Cals, } 2010 \\
\text { Subtotal }(95 \% \mathrm{Cl})\end{array}$ & 33 & $\begin{array}{l}73 \\
73\end{array}$ & 47 & $\begin{array}{l}78 \\
78\end{array}$ & $\begin{array}{l}45.1 \% \\
45.1 \%\end{array}$ & $\begin{array}{c}0.75[0.55,1.02] \\
0.75[0.55,1.02]\end{array}$ & & \\
\hline $\begin{array}{l}\text { Total events } \\
\text { Heterogeneity: Not app } \\
\text { Test for overall effect: } Z\end{array}$ & $\begin{array}{r}33 \\
\text { plicable } \\
Z=1.82\end{array}$ & $P=0.0$ & 47 & & & & & \\
\hline 2.1.2 Cluster RCTs (m & lodified $\mathrm{s}$ & ample) & & & & & & \\
\hline $\begin{array}{l}\text { Little, } 2013 \\
\text { Subtotal }(95 \% \mathrm{Cl})\end{array}$ & 52 & $\begin{array}{l}190 \\
190\end{array}$ & 83 & $\begin{array}{l}185 \\
185\end{array}$ & $\begin{array}{l}54.9 \% \\
54.9 \%\end{array}$ & $\begin{array}{c}0.61[0.46,0.81] \\
0.61[0.46,0.81]\end{array}$ & & \\
\hline $\begin{array}{l}\text { Total events } \\
\text { Heterogeneity: Not app } \\
\text { Test for overall effect: } Z\end{array}$ & $\begin{array}{l}52 \\
\text { olicable } \\
Z=3.44\end{array}$ & $P=0.0$ & $\begin{array}{r}83 \\
1006)\end{array}$ & & & & & \\
\hline Total $(95 \% \mathrm{Cl})$ & & 263 & & 263 & $100.0 \%$ & $0.67[0.54,0.82]$ & & \\
\hline Total events & 85 & & 130 & & & & & \\
\hline $\begin{array}{l}\text { Heterogeneity: } \operatorname{Tau}^{2}= \\
\text { Test for overall effect: }\end{array}$ & $\begin{array}{l}0.00 ; \mathrm{Chi} \\
\mathrm{z}=3.77\end{array}$ & $\begin{array}{l}=0.96 \\
P=0.0\end{array}$ & $\begin{array}{l}6, d f=1 \\
002)\end{array}$ & $=0.33$ & $3) ;\left.\right|^{2}=0 \%$ & 0.2 & $\begin{array}{c}1 \\
0.5 \\
\text { Favours CRP }\end{array}$ & $\frac{1}{2}$ \\
\hline
\end{tabular}

(a) Upper RTI

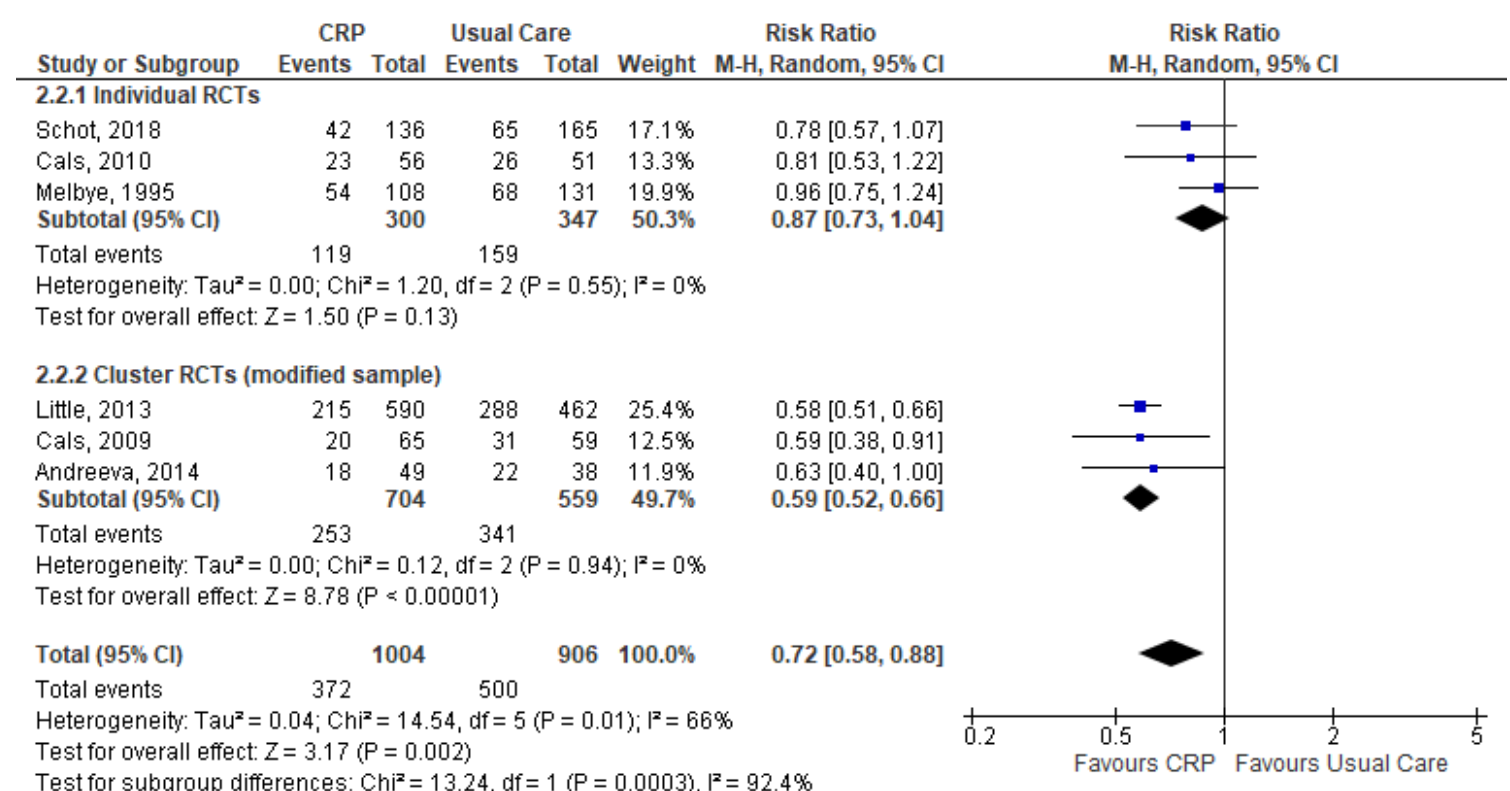

(b) Lower RTI

Figure 3. Comparison: CRP-POCT versus usual care. Antibiotic prescribing at index consultations by type of RTI: (a) Upper RTI; (b) Lower RTI. CRP, C-Reactive Protein Point Of Care Test; RCTs, Randomised Controlled Trials; M-H, Mantel-Haenszel; CI, Confidence Interval; df, degrees of freedom; $\mathrm{I}^{2}$, heterogeneity between trials.

Subgroup analysis by age groups also showed significantly lower antibiotic prescribing for adults and not significantly lower antibiotic prescribing for children in the CRP-POCT group ( $\geq 18$ years $(n=8), 39.8 \%$ vs. $56.0 \%$ : RR $0.76,95 \%$ CI 0.64 to $0.89, p=0.0007, \mathrm{I}^{2}=76 \%$; $<18$ years $(n=6), 34.3 \%$ vs. $41.8 \%$ : RR $0.90,95 \%$ CI 0.73 to $1.11, p=0.31, \mathrm{I}^{2}=67 \%$ ) (Figure 4 ). 


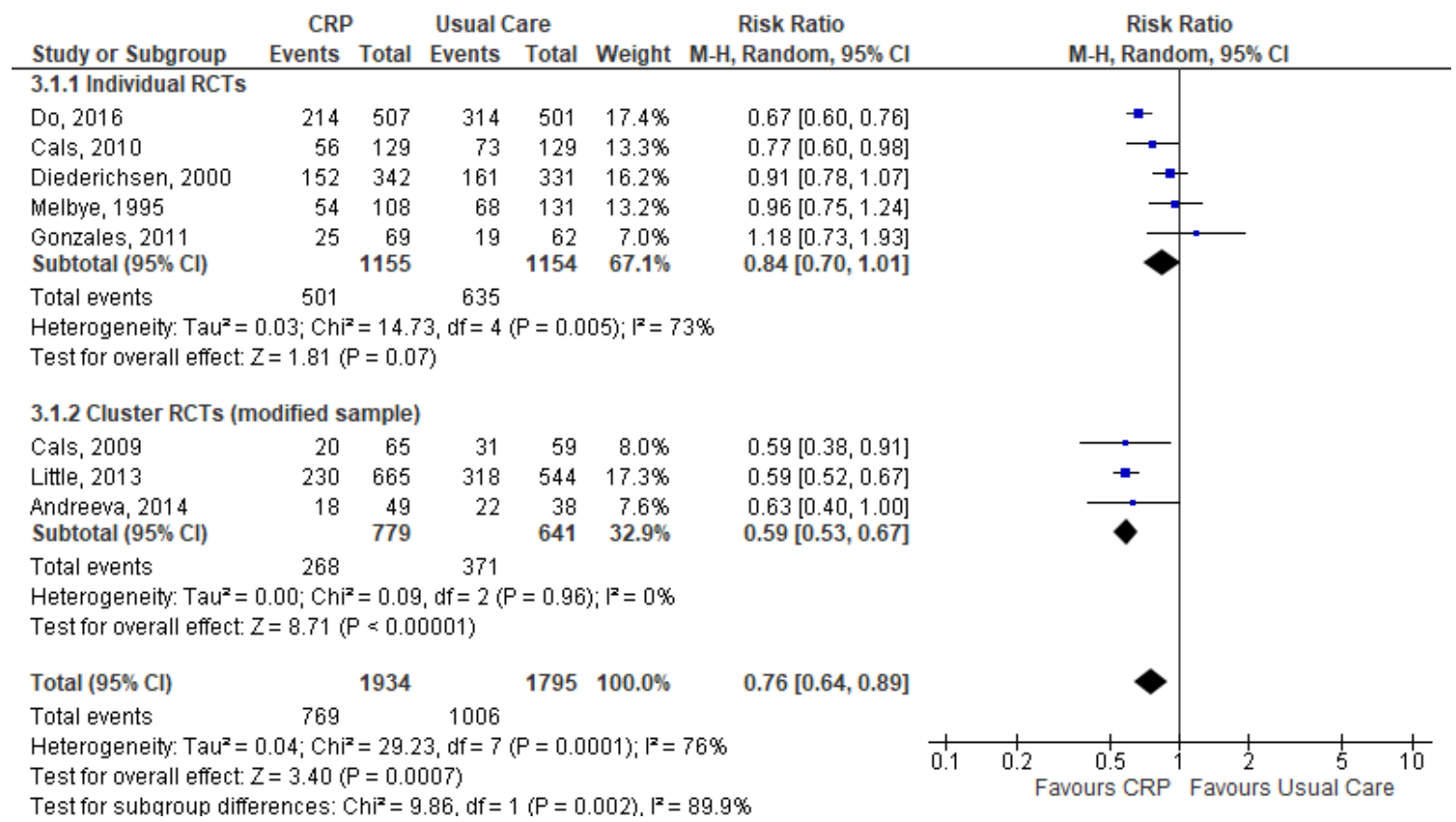

(a) Adults

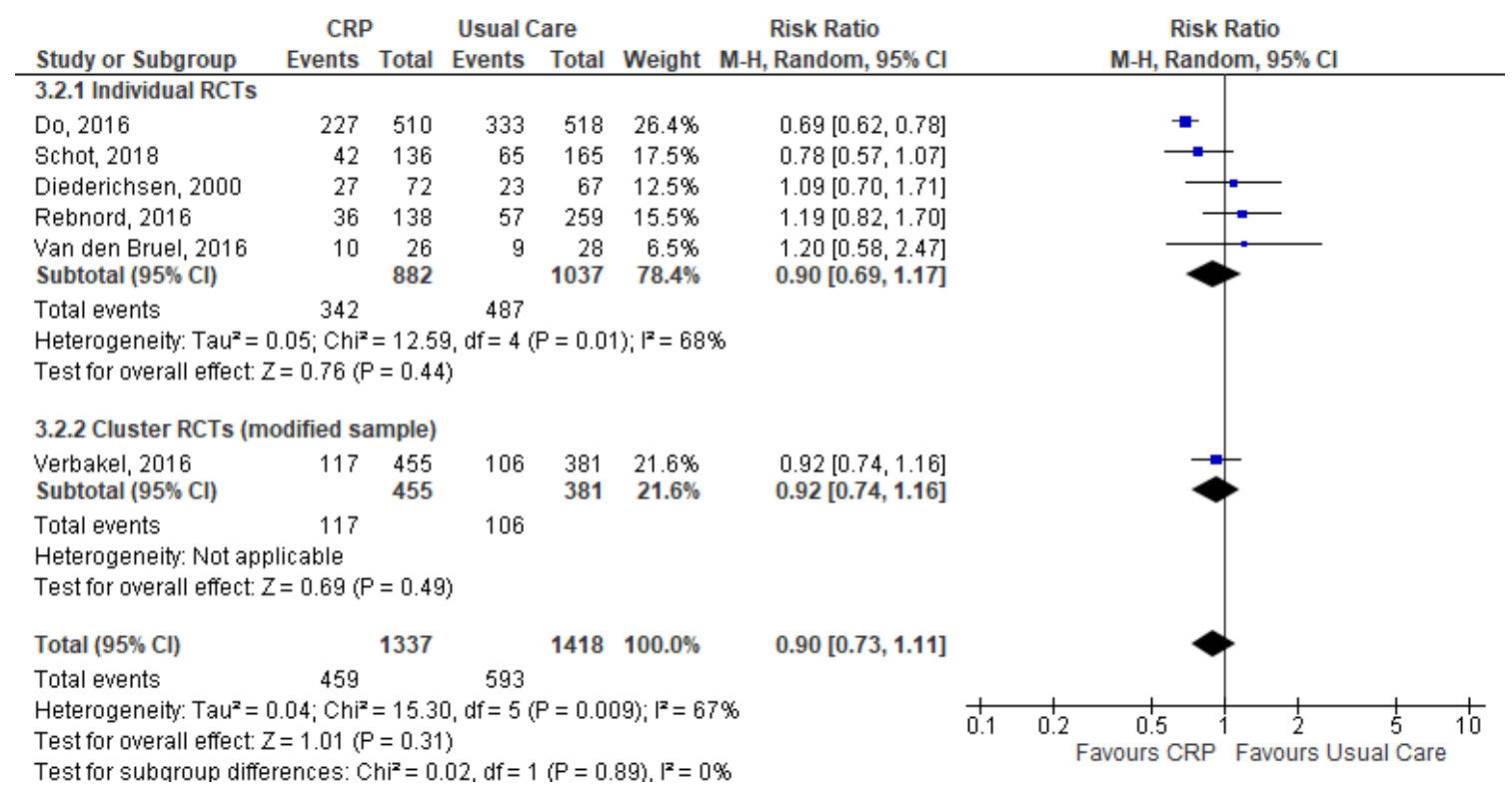

(b) Children

Figure 4. Comparison: CRP-POCT versus usual care. Antibiotic prescribing at index consultations by age group: (a) Adults; (b) Children. CRP, C-Reactive Protein Point Of Care Test; RCTs, Randomised Controlled Trials; M-H, Mantel-Haenszel; CI, Confidence Interval; df, degrees of freedom; $\mathrm{I}^{2}$, heterogeneity between trials.

Subgroup analysis showed significantly lower antibiotic prescribing when CRP cut-off guidance was applied to withhold antibiotics $(n=8,37.6 \%$ vs. $54.4 \%$ : RR $0.75,95 \%$ CI 0.65 to $0.87, p=0.0001$, $\mathrm{I}^{2}=72 \%$ ) and not significantly lower antibiotic prescribing when CRP guidance in five studies was not clear or not applied to withhold or initiate antibiotics (Supplementary Materials).

Subgroup analysis by CRP guidance and age groups demonstrated significantly lower antibiotic prescribing among adults in whom clinical CRP cut-off guidance was applied to withhold antibiotics $\left(\geq 18\right.$ years $(n=8), 38.8 \%$ vs. $54.4 \%$ : RR $0.72,95 \%$ CI 0.62 to $0.85, p<0.0001, \mathrm{I}^{2}=68 \%$ ) (Figure 5). 
The pooled estimate also showed significantly lower antibiotic prescribing among children in whom CRP cut-off guidance was applied to withhold antibiotics ( $<18$ years $(n=2), 31.9 \%$ vs. $43.5 \%$ : RR 0.56 , $95 \%$ CI 0.33 to $\left.0.95, p=0.03, \mathrm{I}^{2}=79 \%\right)$.

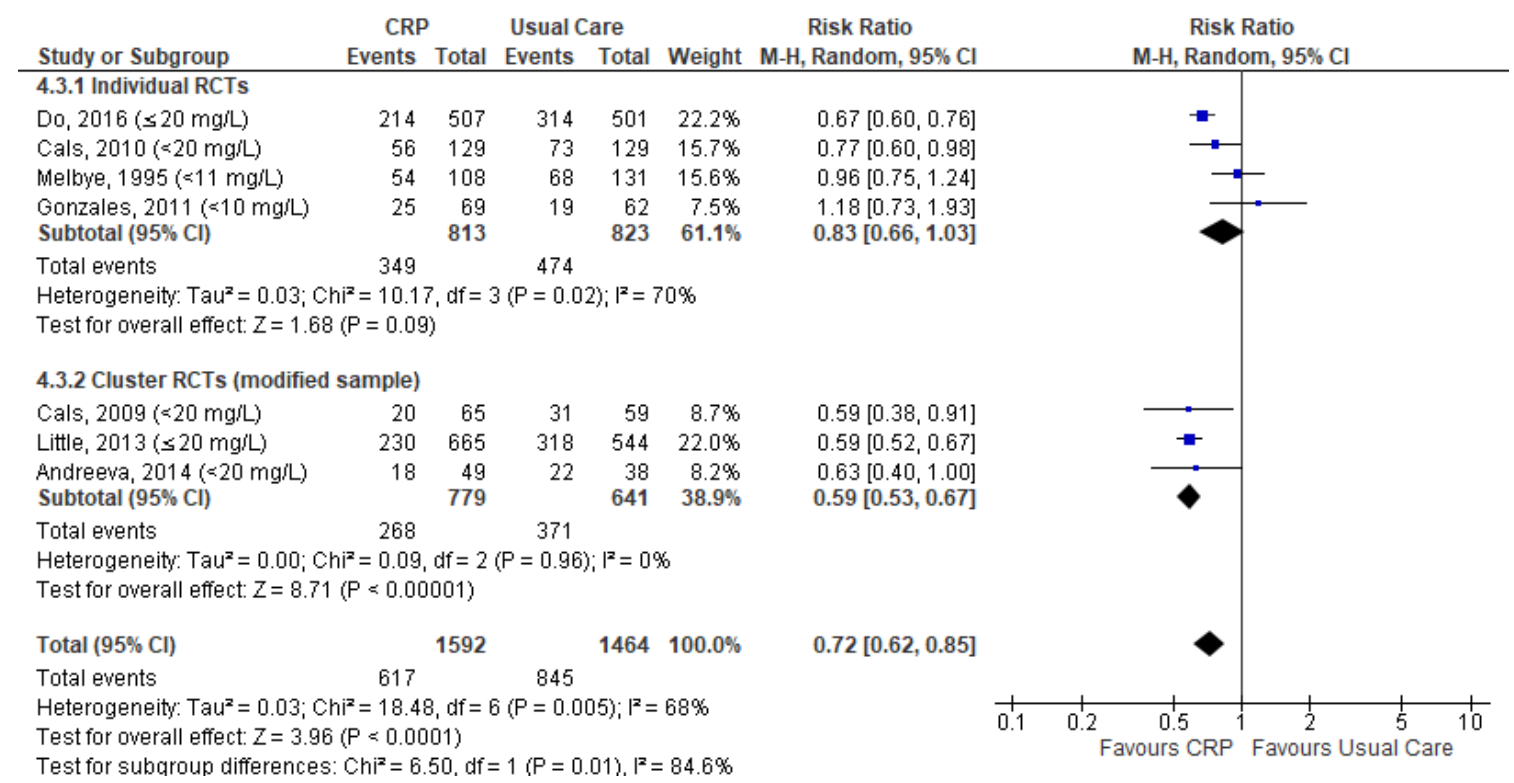

(a) Adults with CRP (cut-off) guidance applied to withhold antibiotics

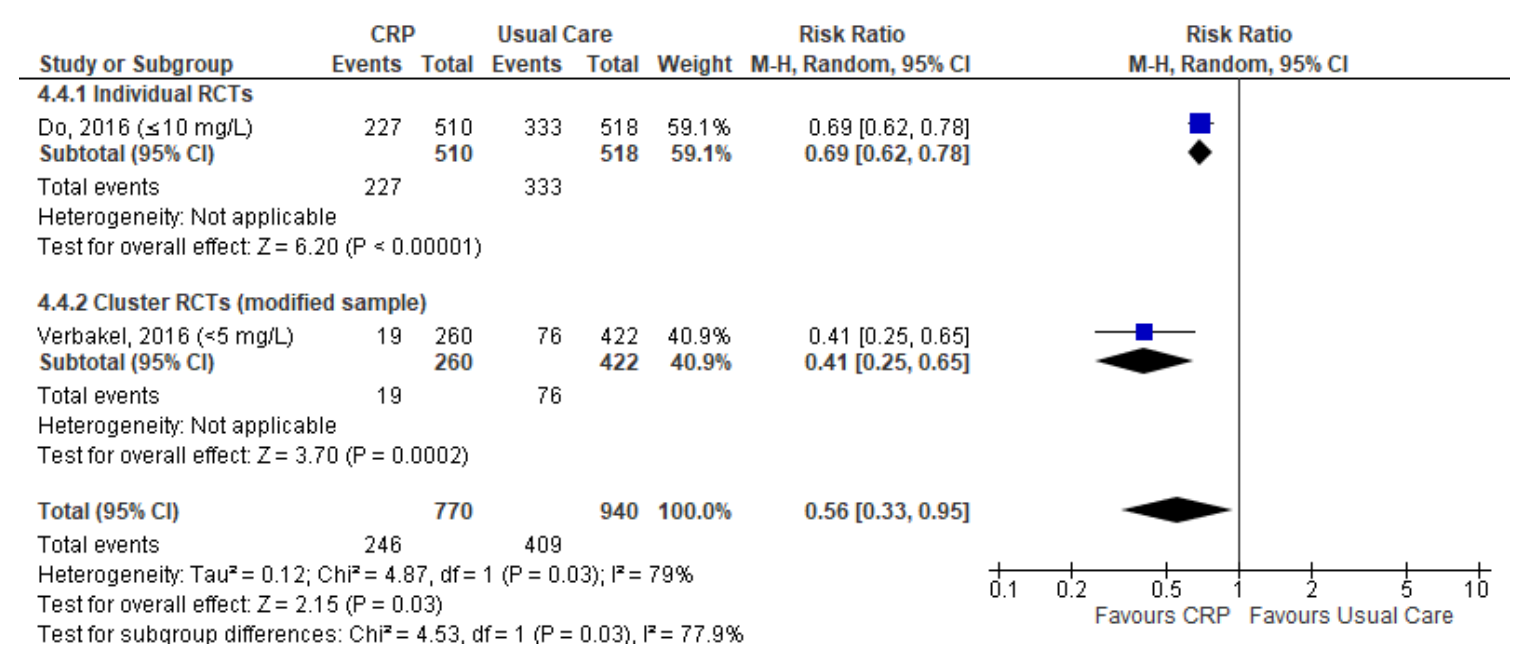

(b) Children with CRP (cut-off) guidance applied to withhold antibiotics

Figure 5. Comparison: CRP-POCT versus usual care. Antibiotic prescribing at index consultations by age group with CRP (cut-off) guidance to withhold antibiotics: (a) Adults; (b) Children. CRP values recommended to withhold antibiotics are presented within brackets. CRP, C-Reactive Protein (Point Of Care Test); RCTs, Randomised Controlled Trials; M-H, Mantel-Haenszel; CI, Confidence Interval; df, degrees of freedom; $\mathrm{I}^{2}$, heterogeneity between trials.

Subgroup analysis by clinical settings showed significantly lower antibiotic prescribing among patients in the CRP group who attended GP practices $(n=7,35.8 \%$ vs. $47.7 \%$ : RR $0.77,95 \% \mathrm{CI} 0.64$ to $0.94, p=0.009, \mathrm{I}^{2}=81 \%$ ) or outpatient (hospital and healthcare centres) services ( $n=2,44.7 \%$ vs. 66.7\%: RR 0.67, 95\%CI 0.62 to $0.73, p<0.00001, \mathrm{I}^{2}=0 \%$ ) but not in other settings from five studies (Supplementary Materials).

Overall between-study heterogeneity was not significant in the subgroup of URTI $\left(\mathrm{I}^{2}=0 \%, n=2\right)$, clinical settings other than GPs $\left(\mathrm{I}^{2}=0-3 \%, n=2-5\right.$ studies $)$ and the set of cluster RCTs $\left(\mathrm{I}^{2}=0 \%, n=1-3\right.$ 
studies) for LRTI, adults, and adults with CRP (cut-off) guidance. In all other subgroups, heterogeneity remained substantial to considerable.

Antibiotic Prescribing Rate during Patient Follow-Up and Longer-Term Effects

Meta-analysis of seven studies demonstrated no significant difference between CRP-POCT and usual care in the rates of antibiotic prescribing at any point during 28 days of follow-up, with moderate between-study heterogeneity ( $36.3 \%$ vs. $41.7 \%$ : RR $0.85,95 \% \mathrm{CI} 0.72$ to $1.02, p=0.08, \mathrm{I}^{2}=48 \%$ ). The individual effect estimate of one study showed significantly lower antibiotic prescribing at 12 months in the same GP practice $(43.4 \%$ vs. $51.4 \%$ : RR $0.84,95 \%$ CI 0.77 to $0.92, p=0.0002)[67,78]$. Individual effect estimates of two studies showed a non-significant trend towards lower antibiotic prescribing in the CRP-POCT group at 3 months [61] or 3.5 years [70] of testing.

\subsubsection{Sensitivity Analysis and Meta-Regression}

The pooled estimate in the meta-analysis of antibiotic prescribing at index consultation was not significantly affected by systematically excluding any study with clinical or methodological variation; heterogeneity remained substantial (Supplementary Materials). The pooled estimate slightly reduced in some cases, but the direction of effect remained significant towards improvement with CRP-POCT. Analyses by continents showed the effect remained significant in favour of CRP-POCT.

Using meta-regression, $59.0 \%$ of the between-study heterogeneity $\left(\mathrm{I}^{2}=74.4 \%, p<0.001\right)$ could be explained by three modifiers $\left(\mathrm{I}^{2}=47.9 \%, p=0.032\right.$ ), including the year of publication ( $\mathrm{RR} 0.86,95 \% \mathrm{CI}$ 0.75 to $0.97, p=0.014$ ), age (children: RR $1.21,95 \%$ CI 1.02 to $1.43, p=0.03$ ), and CRP cut-off guidance (RR $0.86,95 \%$ CI 0.71 to $1.04, p=0.11$ ) (Supplementary Materials).

\subsubsection{Secondary Outcomes}

Clinical Recovery and Resolution of Symptoms

Meta-analyses of three studies demonstrated no significant difference between CRP-POCT and usual care in the number of patients with clinical recovery at 7 and 28 days, with no heterogeneity between trials ( 7 days, $51.7 \%$ vs. $52.8 \%$ : RR $1.03,95 \%$ CI 0.93 to $1.14, p=0.53, \mathrm{I}^{2}=0 \% ; 28$ days, $77.8 \%$ vs. $75.3 \%$ : RR $0.95,95 \% \mathrm{CI} 0.70$ to $1.28, p=0.72, \mathrm{I}^{2}=0 \%$ ). Individual estimates of two studies also showed no significant differences between CRP-POCT and usual care in clinical recovery at 7 days [69], in the time (number of days) to full clinical recovery at 28 days [69], or in the mean symptom severity scores [67]. Individual estimates of one study showed significantly longer-time (mean number of days) to the resolution of symptoms among patients in the CRP-POCT group compared with usual care (MD 0.33, 95\%CI 0.03 to $0.63, p=0.03$ ) [67]. This difference, however, was not significant between CRP-POCT and usual care in another study [65].

Visit Duration and Visits at Follow-Up

Individual estimates of one study showed no significant differences between CRP-POCT and usual care in the length of patients' visits [68]. One trial showed a reduction in the number of patients with RTI who visited their physician within 3.5 years of follow-up, which started after the first 28 days [70].

\section{Re-Consultations and Intention to Re-Consult}

Meta-analysis of eight studies demonstrated a significant increase in re-consultations among patients in the CRP-POCT group with low between-study heterogeneity ( $13.5 \%$ vs. $9.7 \%$ : RR 1.33 , $95 \% \mathrm{CI} 1.14$ to $1.57, p=0.0004, \mathrm{I}^{2}=3 \%$ ). Individual estimates of one study showed significantly more patients in the CRP-POCT group had the intention to re-consult for future similar symptoms $(74.8 \% \mathrm{vs}$. 61.0\%: RR 1.23, 95\%CI 1.03 to $1.46, p=0.02$ ) [69]. This difference, however, was not significant between CRP-POCT and usual care in another study [70]. 
Referrals to Secondary Care

Meta-analysis of three studies demonstrated no significant difference between CRP-POCT and usual care in the number of patients referred to hospital with low between-study heterogeneity $(2.9 \%$ vs. $4.5 \%$ : RR $0.84,95 \% \mathrm{CI} 0.44$ to $1.61, p=0.60, \mathrm{I}^{2}=18 \%$ ). Individual estimates of one study also showed no significant differences between CRP-POCT and usual care in the number of patients with non-urgent referrals to secondary care (specialists or emergency department (ED)) at the time of re-consultations, or at 3 months [61].

Admissions to Hospital and Mortality

Meta-analysis of five studies demonstrated no significant difference in hospital admissions between CRP-POCT and usual care with no between-study heterogeneity $(1.2 \%$ vs. $0.92 \%$ : RR 1.18 , $95 \% \mathrm{CI} 0.65$ to $2.13, p=0.59, \mathrm{I}^{2}=0 \%$ ). Individual estimates of one study also showed no significant differences between CRP-POCT and usual care in hospital admissions as adverse events due to RTI at 3.5 years [70]. One study found no deaths in the CRP-POCT or usual care groups [69].

Ordering of Investigations

Individual estimates of two studies showed no significant difference between CRP-POCT and usual care in the number of patients for whom additional tests were ordered [62,63]. Individual estimates of one study showed significantly less patients in the CRP-POCT group for whom chest X-rays were ordered ( $55.5 \%$ vs. $75.7 \%$ : RR $0.73,95 \% \mathrm{CI} 0.59$ to $0.91, p=0.005)$ [66]. This difference, however, was not significant between CRP-POCT and usual care in another study [68].

\section{Patient Satisfaction and Patient Enablement}

Meta-analysis of three studies showed no significant difference in the number of patients who were satisfied with their medical consultations in the CRP-POCT group compared with usual care ( $88.6 \%$ vs. $86.8 \%$ : RR $0.82,95 \%$ CI 0.55 to $1.21, p=0.31, \mathrm{I}^{2}=48 \%$ ). Between-study heterogeneity was moderate. Individual estimates of two studies showed no significant difference in the score of the patient enablement index among patients in the CRP-POCT group compared with usual care $[69,70]$.

\subsubsection{Combined Benefit and Harm Effect of CRP-POCT}

Exposure to usual care including CRP-POCT compared with usual care alone would result in an absolute risk reduction of $13.2 \%$ in antibiotic prescribing (38.2\% vs. $51.4 \%)$ at index consultations $(\mathrm{NNTB}=8)$. Exposure to usual care including CRP-POCT would also result in an absolute risk increase of $3.8 \%$ in re-consultations $(13.5 \%$ vs. $9.7 \%)(\mathrm{NNTH}=27)$. Considering both the reduction in antibiotic prescribing at index consultations and the increase in re-consultations, the NNTnet of usual care including CRP-POCT is 11 . That is, on average, for every 11 patients getting usual care including CRP-POCT, one patient will experience net benefit, i.e., treatment without antibiotics.

\subsubsection{Publication Bias}

We were able to assess publication bias for the primary outcome of antibiotic prescribing at index consultations. The funnel plot was symmetrical, and the Egger's statistic confirmed no evidence of positive publication bias $(p=0.092)$ (Supplementary Materials). There were too few studies (range, $\mathrm{n}$ : 2-8) to assess publication bias for other outcomes.

\section{Discussion}

In this systematic review and meta-analysis, we comprehensively summarised the available evidence from 13 RCTs on the clinical effectiveness of CRP-POCT with usual care in reducing antibiotic prescribing for RTIs in primary care. Based on evidence of moderate to high- quality, our results demonstrate that CRP-POCT can reduce immediate (at index consultations) antibiotic prescribing in 
patients presenting to primary care with upper and lower RTIs. CRP-POCT in combination with CRP (cut-off) guidance effectively reduced immediate antibiotic prescribing in children and enhanced the effect already gained by performing CRP-POCT in adults. Although there was a significant increase in the rates of re-consultation $(\mathrm{NNTH}=27)$ within 30 days of testing, an NNTnet of 11 indicates that the benefit in reducing antibiotic prescribing $(\mathrm{NNTB}=8)$ outweighs the harm when adding CRP-POCT to usual care. Most of the evidence originates from the GP setting where, in addition to the (hospital) outpatient care setting, CRP-POCT appears most effective in reducing antibiotic prescribing. We found no significant effect of CRP-POCT in the rates of clinical recovery, resolution of symptoms, hospital admissions, referrals to secondary care, or in the ordering of further investigations. One study reported no deaths. Limited evidence showed that CRP-POCT did not significantly reduce antibiotic prescribing at any point during 28-days of follow-up $(n=7)$ and that antibiotic prescribing at the index consultation was still lower in the GPs intervention at 12 months $(n=1)$.

CRP-POCT is a simple test that is being widely used in many countries to help clinicians identify whether patients with RTIs need antibiotics and to consequently reduce unnecessary antibiotic prescribing. The test can be performed within five minutes, helping clinicians with rapid decision-making during the consultation. Considering the global importance of antimicrobial resistance and its association with the extent of antibiotic consumption, compared with previous reviews [25,26], we found a slowly increasing volume of evidence from empirical research ( $n=13$ RCTs) mostly published in English. The studies were carried out mostly in high-income countries, predominantly in general practices in the northern European setting, mainly the Netherlands. The evidence represents populations of all ages (range: 0-90), the majority of whom were young adults (mean age: 26.4, SD 15.0), mostly women (56\%), with signs and symptoms of RTIs. The results from this review are based on published data and should be considered within this context.

\subsection{Strengths and Limitations of this Review}

Our systematic review complements and expands on previous evaluations with a similar scope. As there is a continued relevance of the topic and findings, new studies have been published since. Our review benefits from adhering to rigorous systematic review methodology. It was based on clearly defined inclusion criteria and critical appraisal of the evidence. We restricted our review to the inclusion of RCTs only since these allow the estimation of causal effects with a lower risk of bias. Where possible, we used meta-analyses to assess the impact of CRP-POCT and to synthesize the evidence. We also carefully addressed the heterogeneity of the study results with predefined and plausible sources of heterogeneity using meta-regression analyses.

In particular, our review benefits from the inclusion of international literature published not only in English and without restriction to countries, nor to the type of health care professionals who prescribed or dispensed antibiotics, or to the year of publication. We made considerable efforts to identify all relevant studies by applying comprehensive and exhaustive literature searches in several peer-reviewed and grey literature sources between 2017 and 2019. We also conducted manual searches and received feedback from experts and colleagues (up to May 2020) about potentially relevant studies for the review, thus increasing the likelihood of identifying more contemporary literature.

The results of our systematic review are limited by the slowly increasing volume of the available literature and by the large and heterogeneous group of outcomes that resulted from our comprehensive approach. Some outcomes were variably reported across studies and in some cases, there was a dearth of data, e.g., mortality, or there was no more than one study per outcome affecting the ability to aggregate data in meta-analyses. A paucity of studies without the use of CRP guidance in children and a lack of data from older adults also limited the conclusions of our review.

\subsection{Unanswered Questions and Future Research}

The majority of participants were young adults (mean age: 26.4, SD 15.0), with merely four studies carried out exclusively in the paediatric population. Moreover, our subgroup and meta-regression 
analyses revealed that between-study heterogeneity can be explained by age, year of publication, and CRP guidance. In line with a previous review, CRP guidance showed the same direction in explaining heterogeneity [26], although in our analyses this was a non-significant source of heterogeneity likely due to low power. Only eight studies reported on the use of CRP (cut-off) guidance: six in adults, one in children, and one included both adults and children. Moreover, our analyses showed more pronounced effects when a more restrictive CRP (cut-off) guidance to withhold antibiotics was applied. This suggests the need for more studies not only in children in whom CRP (cut-off) guidance is applied but also in older adults, who often present a wide range of comorbidities, are generally under multiple medications, and for whom CRP cut-off values and guidance may differ from other age groups. Studies could also add to the body of evidence by reporting results by age groups and CRP guidance. Newly planned [83] and ongoing [84] trials may help to answer these questions.

The potential effect of CRP-POCT on increasing re-consultations merits consideration in future research. This result was mainly shaped by one study in a meta-analysis. Delayed prescribing was recommended as an option when CRP values were intermediate $(20-100 \mathrm{mg} / \mathrm{L})$ and if illness severity did not require immediate antibiotics. Whether these factors or illness deterioration prompt physicians to request subsequent visits or influence patient awareness for the need of reassurance about their illness should be further examined. Intermediate CRP levels may be more difficult to interpret and may benefit from further guidance [22]. GPs have shown to comply with professional guidelines in up to $70 \%$ of their management decisions [85], are generally positive about CRP-POCT, and have expressed both the need of proper indication (cut-offs) to interpret POCT and skills training to safely use POCT [86]. Depending on the healthcare system and the available financial structures (e.g., fee-for-service, budget consideration on the physician side), an increase in re-consultations might also be a barrier for CRP-POCT's implementation in routine clinical practice.

Furthermore, RTIs were not categorised based on their anatomic involvement in $54 \%$ of the studies, limiting an aggregated analysis of their effect by RTI type, and only two studies contributed to the effect of URTIs. Although it was possible to look at the effect of clinical setting, there were more types of 'other' settings than the number of studies contributing to the effect per setting to produce a meaningful comparison with GPs. In addition, our subgroup analyses showed that heterogeneity may also be explained by the type of RTI and healthcare setting. Using a more standard classification for RTIs and stratifying by clinical setting would be useful to further explore and clarify the effects of CRP-POCT.

Another key question is whether the effect of CRP-POCT sustains over a long-time span. Finding a significant effect at 12 months $(n=1)$ but not at 28 days $(n=7)$ or other follow-up episodes ( 3 months and 3.5 years) was supported by a few studies (range, $n: 1-7$ ), half of which comprised small samples. It was also unclear if or how CRP-POCT was used over a longer-term. Although the short-term effect of CRP-POCT in our review is about the treatment of RTIs and not about its effect on patients' and physicians' behaviour after initial visits, long-term studies in larger populations could clarify the use of CRP-POCT and this effect.

Finally, the quality of the evidence was moderate to high due to performance bias, which is unlikely to change in future studies due to the inherent nature of the intervention. A sham control would be difficult to implement to blind control-group participants with a procedure mirroring CRP-POCT. Pragmatic (open-label) trials, however, have the advantage of producing evidence and estimates that are closer to real-life and more valuable for health economics analyses.

\subsection{Findings in Context with other Interventions and Reviews}

CST for physicians has shown a similar effect in lowering antibiotic prescribing when individually compared with CRP-POCT or usual care [67]. In our review, including one study with a factorial intervention consisting of CST added to CRP-POCT enhanced the overall effect in reducing antibiotic prescribing [70]. The study sample was small and the overall pooled effect changed by a small amount but remained significant after removing the study. Another study also reporting data (not used in our 
review) on similar factorial interventions showed that CST added to CRP-POCT not only enhanced the overall effect but this sustained at 12 months, and the rate of re-consultation was not significant between groups [67]. This suggests that the combined effect of CST and CRP-POCT may have a positive impact on patient behaviour, self-awareness, and management of RTIs. CST has also shown a sustainable effect [78] and appears more cost-effective than CRP-POCT alone [27]. Delayed prescribing has also been shown to reduce antibiotic use [87] and has been integrated into the National Institute for Health and Care Excellence (NICE) guidelines to aid decision-making when CRP levels are intermediate [24].

Procalcitonin has also been tested as a relevant inflammatory marker to reduce antibiotic prescribing for acute RTIs although it has no added value to signs and symptoms in the diagnosis of pneumonia [88]. Moreover, procalcitonin is not yet routinely available as a rapid POCT in primary care and its cost-effectiveness is still to be evaluated [25].

Previous evaluations with a similar scope $[25,26,89]$ also found a significant reduction in antibiotic prescribing when using CRP-POCT. The most relevant to the scope of our review is a Cochrane review [25], which was based on six RCTs (3200 patients, 180 children)-also appraised in another review [89] - and showed an uncertain degree of antibiotic reduction, a non-significant increase in re-consultations, but a potential increase in hospital admissions. It was limited by the paucity of studies in children and studies using CRP guidance. The most recent review focused on acute infections in ambulatory care and based on 10 RCTs [26] showed that CRP guidance in addition to CRP-POCT reduced antibiotic prescribing and found no effect on re-consultations, hospital admissions, or other outcomes, and a relative lack of studies in children. Another review focused on LRTI and based on five RCTs, appraised in the Cochrane review [25], concluded that evidence did not support the use of CRP-POCT in primary care, but meta-analyses were not performed [90]. The reviews used $2 \times 2$ factorial group data from two cluster RCTs adding the effect of CST to both CRP-POCT and usual care.

Our review included 13 RCTs, all relevant to the study of CRP-POCT to reduce antibiotic prescribing for RTIs in primary care. It included all acute RTIs, appraised the impact of CRP-POCT on a wider range of patient-relevant and process outcomes and relevant subgroups not addressed in previous reviews, e.g., type of RTIs and clinical setting. Whenever possible, it used individual group rather than factorial groups to aggregate data in meta-analyses to minimise confounding of the effect of CRP-POCT versus usual care. It demonstrated a more robust effect of CRP-POCT in reducing antibiotic prescribing for RTIs, although with an increased rate of re-consultation, but no effect on hospital admissions. The effect on clinical recovery, ordering further investigations, and other relevant outcomes were similar to other reviews. In addition to the paucity of studies without the use of CRP guidance in older adults, our review also identified that the paucity of studies in children previously reported by other reviews has only slowly been addressed. Similarly, our review also identified that reporting of current and new patient-relevant and process outcomes is gradually increasing.

\section{Literature Review Methods}

This study is part of a series of systematic reviews designed to assess the evidence of interventions to improve antibiotic use in patients with RTIs in primary care. Its methods are described in detail elsewhere [91]. It follows the guidelines for the reporting of systematic reviews and meta-analyses (PRISMA) (see Supplementary Materials) [92]. The protocol is registered on PROSPERO [91] and followed the recommendations for systematic reviews of healthcare interventions [93,94].

\subsection{Search Strategy}

We searched for studies using 11 sources of literature by placing no restrictions on the language of publication, publication date, country of origin, or reported outcomes. We searched MEDLINE (EBSCOHost), EMBASE (Elsevier), The Cochrane Library (Wiley), CINHAL (EBSCOHost), PsychINFO (EBSCOHost), and Web of Science from their period of inception up to June 2017 (see supplementary materials). We also searched the Latin American and Caribbean Literature on Health Sciences (LILACS), Turning Research Into Practice database (TRIP), and the system for information on grey literature in 
Europe (http://opengrey.eu/) from all available dates until March-May 2019. Additionally, we screened the reference lists of included studies and relevant reviews published up to 2019. Experts and colleagues also provided us (up to May 2020) with potentially relevant studies.

\subsection{Eligibility Criteria}

We included studies investigating the use of CRP-POCT as an intervention to guide clinicians' antibiotic prescribing decisions. Studies were eligible if they were randomised controlled trials (RCTs), cluster RCTs, or quasi-RCTs comparing the clinical effectiveness of CRP-POCT with usual care. RCTs had to be carried out in patients, both adults and children of all ages, presenting with common acute RTIs to primary care settings. We defined primary care as outpatient care services, including in-hours (e.g., paediatric and family practice clinics) and out-of-hours (e.g., walk-in clinics, emergency departments, hospital outpatients) services. We further limited study eligibility to RCTs reporting quantitative data for the outcomes of interest. We excluded RCTs in patients with COPD exacerbations and/or other pre-existing chronic pulmonary diseases, as well as RCTs from in-patient (e.g., hospitalised) settings.

\subsection{Outcome Assessment}

We defined the primary outcome as the effect of CRP-POCT on the rates of (any) antibiotics prescribed at the index consultation or any reported follow-up episode. We defined secondary outcomes as the effect of CRP-POCT on clinical recovery or resolution of symptoms, re-consultations, visit duration, RTIs during follow-up, ordering of additional or other diagnostic investigations, referral to hospital, hospital admission, mortality, patient enablement, and patient satisfaction.

\subsection{Selection of Studies and Data Extraction}

Four reviewers independently and in pairs performed the screening and selection of records retrieved from the searches. The first screening of titles and abstracts was performed for relevance and a second screening was performed to select potentially relevant publications for full-text evaluation. The first selection of full texts consisted of publications on POCT followed by a second selection of publications on CRP-POCT. Where necessary, we translated titles, abstracts, and full texts following the recommendations by the Centre for Research in Evidence-Based Practice [95]. We set out to prioritise the selection of studies in English, Spanish, and German, but we expanded to other languages where publications fit the inclusion criteria based on the translation of titles, abstracts, and/or full texts. Data extractions were performed using a priori developed forms by one reviewer and were independently verified by a second reviewer. Studies reported across more than one publication were treated as one unit. Differences in the judgment of study selection and data extractions were resolved by discussion, involving a third reviewer as arbitrator or both. The final list of included studies was confirmed with the team.

\subsection{Assessment of Methodological Quality and Risk of Bias}

Two reviewers independently assessed in duplicate the quality features of the included studies and differences were resolved by discussion. As detailed in the protocol [91], following established guidelines, we did not calculate a composite score [96], but we determined the internal validity (risk of bias) of studies by rating the adequacy of the studies' core items based on the Cochrane risk of bias guidelines for RCTs [94]. We anticipated that due to the nature of the intervention, blinding patients and clinicians would not be possible, but blinded outcome assessment and reporting could help to identify whether studies are prone to selective reporting. We also assessed if all participants were followed up for the same length of time. 


\subsection{Statistical Analyses and Data Synthesis}

We followed available guidelines to incorporate cluster-RCTs and to assess missing data [94]. We estimated the intervention effects using the unadjusted risk ratios (RRs) for binary data or the unadjusted weighted mean differences (MDs) for continuous data. We report the summary statistics and 95\% confidence intervals (CIs) together with the exact $p$-values where data allowed their calculation. If at least three studies could be combined, a meta-analysis was performed in Cochrane RevMan (version 5.4.0) using the random-effects model due to clinical heterogeneity [97]. We quantified heterogeneity with the $\mathrm{I}^{2}$ statistic as low $(\leq 25 \%)$, moderate $(50 \%)$, substantial (up to $75 \%$ ), and considerable ( $>75 \%)$ [98].

We limited subgroup, sensitivity, and meta-regression analyses to the primary outcome. We explored the effects of the interventions by pooling data into pre-specified subgroup analyses, including the type of randomisation (individual patient and cluster level), population groups (children and adults), RTI type, use of CRP (cut-off) guidance, and clinical setting. With sensitivity analyses, we assessed the effect of studies with dubious criteria for inclusion, unclear definitions of RTI, at-risk populations, special RCT design, different CRP analysers, or different continents. We performed a random effect meta-regression using the metafor package in $\mathrm{R}$ (version 3.6.1) to explore whether between-study heterogeneity could be explained by a set of modifiers. The model included publication year (centred with the mean of publication year $=2010$ ), age groups (adults, adults and children, children), and whether CRP cut-off guidance was provided (no/yes). Where there were at least 10 trials per outcome, we assessed the potential for publication bias and small study effects by the inspection of funnel plots and by the Egger's test for asymmetry of funnel plots [99].

\subsection{Combined Benefit and Harm Effect of CRP-POCT}

For the outcome of antibiotic prescribing and any outcome resulting in potential harm due to the intervention, we measured the combined benefit and harm effects of CRP-POCT (NNTnet) following recent recommendations [100]. The NNTnet metric is based on (1) the number needed to treat for benefit (NNTB), here the average number of patients needed to be seen by a clinician equipped to perform CRP-POCT to see the benefit (treatment without antibiotics) in one additional patient; and (2) the number needed to treat for harm (NNTH), here the average number of patients needed to be seen by a clinician equipped to perform CRP-POCT to see harm (any) in one additional patient.

\section{Conclusions}

So far, evidence of moderate to high quality shows that compared with usual care, using CRP-POCT to guide antibiotic prescribing for (lower and upper) RTIs in primary care can reduce antibiotic prescribing at index consultations especially if cut-off guidance is provided. This reduction in antibiotic prescribing appeared to increase the re-consultation rate but did not affect clinical recovery, resolution of symptoms, or hospital admissions. Limited evidence showed no significant effects of CRP-POCT on antibiotic prescribing at any point during 28 days of follow-up $(n=7)$ but less antibiotic prescribing at the index consultation in the GPs intervention sustained at 12 months $(n=1)$. The increased re-consultations and longer-term effects of CRP-POCT need further evaluation. The overall benefits of CRP-POCT $($ NNTnet $=11)$ on reducing antibiotic prescribing $(\mathrm{NNTB}=8)$ outweigh the potential harms of increased re-consultations $(\mathrm{NNTH}=27)$.

Supplementary Materials: Additional supporting material is contained in the supplementary materials and it is available online at http://www.mdpi.com/2079-6382/9/9/610/s1.

Author Contributions: Conceptualisation and design: N.A.M.-G., S.C., S.N.-J. and O.S.; data extraction forms design and/or testing: N.A.M.-G., F.V., E.K. and A.P.; screening, data extraction and study quality assessment: N.A.M.-G., E.K. and A.P.; verification of data extractions: N.A.M.-G. and E.K.; advice on methodology, analyses and meta-regression: J.Y.J.V.; formal analyses: N.A.M.-G.; data transformations and/or meta-regression analyses: N.A.M.-G. and F.V.; writing-original draft: N.A.M.-G.; manuscript editing: N.A.M.-G., S.C., J.Y.J.V., S.N.-J. and O.S.; referees for selection of studies: S.C., S.N.-J. and O.S.; overall study process: T.R. All authors take 
responsibility for appropriate content, critically revised the manuscript, and approved the version of the manuscript to be published. All authors have read and agreed to the published version of the manuscript.

Funding: This study was supported by the Gottfried und Julia Bangerter-Rhyner-Stiftung, Switzerland (Health Services Research Programme). The funder had no role in the design, data collection, analysis, interpretation of data, the decision to publish, or in the preparation of this manuscript.

Acknowledgments: We are grateful to Annelies Colliers for her help in the initial stage of the review and to Poorvi Gupta for her help in collating grey literature. We are also grateful to Doris Kopp and Martina Gösteli for their assistance with the search strategies. Doris Kopp works at the Library and Research Support Services at the Institute of Social and Preventive Medicine, CTU and BIHAM, University of Bern. Martina Gösteli works at the Library and Research Information Services, University of Zurich.

Conflicts of Interest: The authors declare no conflict of interest.

\section{References}

1. Centers for Disease Control and Prevention. Measuring Outpatient Antibiotic Prescribing. 2020. Available online: https://www.cdc.gov/antibiotic-use/community/programs-measurement/measuringantibiotic-prescribing.html (accessed on 10 June 2020).

2. $\quad$ Fleming-Dutra, K.E.; Hersh, A.L.; Shapiro, D.J.; Bartoces, M.; Enns, E.A.; File, T.M., Jr.; Finkelstein, J.A.; Gerber, J.S.; Hyun, D.Y.; Linder, J.A.; et al. Prevalence of Inappropriate Antibiotic Prescriptions Among US Ambulatory Care Visits, 2010-2011. JAMA 2016, 315, 1864-1873. [CrossRef] [PubMed]

3. Costelloe, C.; Metcalfe, C.; Lovering, A.; Mant, D.; Hay, A.D. Effect of antibiotic prescribing in primary care on antimicrobial resistance in individual patients: Systematic review and meta-analysis. BMJ 2010, 340, c2096. [CrossRef] [PubMed]

4. Goossens, H.; Ferech, M.; Vander Stichele, R.; Elseviers, M. Outpatient antibiotic use in Europe and association with resistance: A cross-national database study. Lancet 2005, 365, 579-587. [CrossRef]

5. Cars, O.; Högberg, L.D.; Murray, M.; Nordberg, O.; Sivaraman, S.; Lundborg, C.S.; So, A.D.; Tomson, G. Meeting the challenge of antibiotic resistance. BMJ 2008, 337, a1438. [CrossRef]

6. Smith, S.M.; Fahey, T.; Smucny, J.; Becker, L.A. Antibiotics for acute bronchitis. Cochrane Database Syst. Rev. 2014, 3, CD000245.

7. Little, P.; Stuart, B.; Moore, M.; Coenen, S.; Butler, C.C.; Godycki-Cwirko, M.; Mierzecki, A.; Chlabicz, S.; Torres, A.; Almirall, J.; et al. Amoxicillin for acute lower-respiratory-tract infection in primary care when pneumonia is not suspected: A 12-country, randomised, placebo-controlled trial. Lancet Infect. Dis. 2013, 13, 123-129. [CrossRef]

8. Butler, C.C.; Hood, K.; Verheij, T.; Little, P.; Melbye, H.; Nuttall, J.; Kelly, M.J.; Molstad, S.; Godycki-Cwirko, M.; Almirall, J. Variation in antibiotic prescribing and its impact on recovery in patients with acute cough in primary care: Prospective study in 13 countries. BMJ 2009, 338, B2242. [CrossRef]

9. Tan, T.; Little, P.; Stokes, T. Antibiotic prescribing for self limiting respiratory tract infections in primary care: Summary of NICE guidance. BMJ 2008, 337, a437. [CrossRef]

10. Lee, G.C.; Reveles, K.R.; Attridge, R.T.; Lawson, K.A.; Mansi, I.A.; Lewis, J.S.; Frei, C.R. Outpatient antibiotic prescribing in the United States: 2000 to 2010. BMC Med. 2014, 12, 96. [CrossRef]

11. European Centre for Disease Prevention and Control. Antimicrobial Resistance Surveillance in Europe. Annual Report of the European Antimicrobial Resistance Surveillance Network (EARS-Net). 2011. Available online: http://www.ecdc.europa.eu/en/publications/Publications/antimicrobial-resistancesurveillance-europe-2011.pdf (accessed on 10 June 2020).

12. Lode, H. Safety and tolerability of commonly prescribed oral antibiotics for the treatment of respiratory tract infections. Am. J. Med. 2010, 123, S26-S38. [CrossRef]

13. Kollef, M.H. Broad-spectrum antimicrobials and the treatment of serious bacterial infections: Getting it right up front. Clin. Infect. Dis. 2008, 47 (Suppl. 1), S3-S13. [CrossRef]

14. Chang, C.Y.; Schiano, T.D. Review article: Drug hepatotoxicity. Aliment Pharmacol. Ther. 2007, 25, $1135-1151$. [CrossRef] [PubMed]

15. Little, P.; Gould, C.; Williamson, I.; Warner, G.; Gantley, M.; Kinmonth, A.L. Reattendance and complications in a randomised trial of prescribing strategies for sore throat: The medicalising effect of prescribing antibiotics. BMJ 1997, 315, 350-352. [CrossRef] [PubMed] 
16. O'Neill, J. Review on Antimicrobial Resistance Antimicrobial Resistance: Tackling a Crisis for the Health and Wealth of Nations; Review on Antimicrobial Resistance: London, UK, 2014. Available online: https://amr-review.org/sites/default/files/AMR\%20Review\%20Paper\%20-\%20Tackling\% 20a\%20crisis\%20for\%20the\%20health\%20and\%20wealth\%20of\%20nations_1.pdf (accessed on 10 June 2020).

17. Tonkin-Crine, S.K.; Tan, P.S.; van Hecke, O.; Wang, K.; Roberts, N.W.; McCullough, A.; Hansen, M.P.; Butler, C.C.; Del Mar, C.B. Clinician-targeted interventions to influence antibiotic prescribing behaviour for acute respiratory infections in primary care: An overview of systematic reviews. Cochrane Database Syst. Rev. 2017, 9, CD012252. [CrossRef]

18. Brookes-Howell, L.; Hood, K.; Cooper, L.; Coenen, S.; Little, P.; Verheij, T.; Godycki-Cwirko, M.; Melbye, H.; Krawczyk, J.; Borras-Santos, A.; et al. Clinical influences on antibiotic prescribing decisions for lower respiratory tract infection: A nine country qualitative study of variation in care. BMJ Open 2012, 2. [CrossRef]

19. Van den Bruel, A.; Haj-Hassan, T.; Thompson, M.; Buntinx, F.; Mant, D. Diagnostic value of clinical features at presentation to identify serious infection in children in developed countries: A systematic review. Lancet 2010, 375, 834-845. [CrossRef]

20. Arnold, S.R.; To, T.; McIsaac, W.J.; Wang, E.E. Antibiotic prescribing for upper respiratory tract infection: The importance of diagnostic uncertainty. J. Pediatr. 2005, 146, 222-226. [CrossRef] [PubMed]

21. Teepe, J.; Broekhuizen, B.D.L.; Loens, K.; Lammens, C.; Ieven, M.; Goossens, H.; Little, P.; Butler, C.C.; Coenen, S.; Godycki-Cwirko, M.; et al. Predicting the presence of bacterial pathogens in the airways of primary care patients with acute cough. CMAJ 2017, 189, E50-E55. [CrossRef]

22. Falk, G.; Fahey, T. C-reactive protein and community-acquired pneumonia in ambulatory care: Systematic review of diagnostic accuracy studies. Fam. Pract. 2009, 26, 10-21. [CrossRef]

23. Woodhead, M.; Blasi, F.; Ewig, S.; Garau, J.; Huchon, G.; Ieven, M.; Ortqvist, A.; Schaberg, T.; Torres, A.; van der Heijden, G.; et al. Guidelines for the management of adult lower respiratory tract infections-full version. Clin Microbiol Infect. 2011, 17 (Suppl. 6), E1-E59. [CrossRef]

24. National Institute for Health and Care Excellence (NICE). Pneumonia: Diagnosis and Management of Communityand Hospital-Acquired Pneumonia in Adults; NICE: London, UK, 2014.

25. Aabenhus, R.; Jensen, J.U.; Jorgensen, K.J.; Hrobjartsson, A.; Bjerrum, L. Biomarkers as point-of-care tests to guide prescription of antibiotics in patients with acute respiratory infections in primary care. Cochrane Database Syst. Rev. 2014, 11, CD010130. [CrossRef] [PubMed]

26. Verbakel, J.Y.; Lee, J.J.; Goyder, C.; Tan, P.S.; Ananthakumar, T.; Turner, P.J.; Hayward, G.; Van den Bruel, A. Impact of point-of-care $C$ reactive protein in ambulatory care: A systematic review and meta-analysis. BMJ Open 2019, 9, e025036. [CrossRef] [PubMed]

27. Oppong, R.; Smith, R.D.; Little, P.; Verheij, T.; Butler, C.C.; Goossens, H.; Coenen, S.; Jowett, S.; Roberts, T.E.; Achana, F.; et al. Cost-effectiveness of internet-based training for primary care clinicians on antibiotic prescribing for acute respiratory tract infections in Europe. J. Antimicrob Chemother. 2018, 73, 3189-3198. [CrossRef] [PubMed]

28. Lubell, Y.; Do, N.T.T.; Nguyen, K.V.; Ta, N.T.D.; Tran, N.T.H.; Than, H.M.; Hoang, L.B.; Shrestha, P.; van Doorn, R.H.; Nadjm, B.; et al. C-reactive protein point of care testing in the management of acute respiratory infections in the Vietnamese primary healthcare setting - a cost benefit analysis. Antimicrob Resist Infect. Control. 2018, 7, 119. [CrossRef]

29. Holmes, E.A.F.; Harris, S.D.; Hughes, A.; Craine, N.; Hughes, D.A. Cost-Effectiveness Analysis of the Use of Point-of-Care C-Reactive Protein Testing to Reduce Antibiotic Prescribing in Primary Care. Antibiotics 2018, 7, 106. [CrossRef]

30. Minnaard, M.C.; van de Pol, A.C.; Hopstaken, R.M.; van Delft, S.; Broekhuizen, B.D.L.; Verheij, T.J.M.; de Wit, N.J. C-reactive protein point-of-care testing and associated antibiotic prescribing. Fam Pract. 2016, 33, 408-413. [CrossRef]

31. Hughes, A.; Gwyn, L.; Harris, S.; Clarke, C. Evaluating a point-of-care C-reactive protein test to support antibiotic prescribing decisions in a general practice. Clin. Pharmacist. 2016, 8.

32. Huddy, J.R.; Ni, M.Z.; Barlow, J.; Majeed, A.; Hanna, G.B. Point-of-care C reactive protein for the diagnosis of lower respiratory tract infection in NHS primary care: A qualitative study of barriers and facilitators to adoption. BMJ Open 2016, 6, e009959. [CrossRef]

33. Hunter, R. Cost-Effectiveness of Point-of-Care C-Reactive Protein Tests for Respiratory Tract Infection in Primary Care in England. Adv. Ther. 2015, 32, 69-85. [CrossRef] 
34. Anthierens, S.; Tonkin-Crine, S.; Cals, J.W.; Coenen, S.; Yardley, L.; Brookes-Howell, L.; Fernandez-Vandellos, P.; Krawczyk, J.; Godycki-Cwirko, M.; Llor, C.; et al. Clinicians' views and experiences of interventions to enhance the quality of antibiotic prescribing for acute respiratory tract infections. J. Gen. Intern. Med. 2015, 30, 408-416. [CrossRef]

35. Nijman, R.G.; Moll, H.A.; Smit, F.J.; Gervaix, A.; Weerkamp, F.; Vergouwe, Y.; de Rijke, Y.B.; Oostenbrink, R. C-reactive protein, procalcitonin and the lab-score for detecting serious bacterial infections in febrile children at the emergency department: A prospective observational study. Pediatr. Infect. Dis. J. 2014, 33, e273-e279. [CrossRef] [PubMed]

36. Llor, C.; Cots, J.M.; Hernández, S.; Ortega, J.; Arranz, J.; Monedero, M.J.; Alcántara, J.d.D.; Pérez, C.; García, G.; Gómez, M.; et al. Effectiveness of two types of intervention on antibiotic prescribing in respiratory tract infections in Primary Care in Spain. Happy Audit Study. Atencion Primaria. 2014, 46, 492-500. [CrossRef] [PubMed]

37. Llor, C.; Bjerrum, L.; Munck, A.; Cots, J.M.; Hernández, S.; Moragas, A. Access to point-of-care tests reduces the prescription of antibiotics among antibiotic-requesting subjects with respiratory tract infections. Respir. Care 2014, 59, 1918-1923. [PubMed]

38. Lacroix, L.; Manzano, S.; Vandertuin, L.; Hugon, F.; Galetto-Lacour, A.; Gervaix, A. Impact of the lab-score on antibiotic prescription rate in children with fever without source: A randomized controlled trial. PLoS ONE 2014, 9, e115061.

39. ClinicalTrials.gov [Internet]. Identifier: NCT04470518. Validation of a Vital Signs and Symptoms Decision Tree and the Effect of a Point-of-care C-Reactive Protein Test, Oxygen Saturation, A Brief Intervention and a Parent Leaflet on Diagnosing, Antibiotic Prescribing Rate and Parental Satisfaction in Acutely Ill Children in Primary Care; National Library of Medicine: Bethesda, MD, USA, 2014. Available online: https:/clinicaltrials.gov/ct2/ show/NCT02024282? cond=NCT02024282\&draw=2\&rank=1 (accessed on 8 September 2020).

40. Peters, C.M.; Schouwenaars, F.M.; Haagsma, E.; Evenhuis, H.M.; Echteld, M.A. Antibiotic prescribing and C-reactive protein testing for pulmonary infections in patients with intellectual disabilities. Br. J. Gen. Pract. 2013, 63, e326-e330. [CrossRef]

41. Oppong, R.; Jit, M.; Smith, R.D.; Butler, C.C.; Melbye, H.; Mölstad, S.; Coast, J. Cost-effectiveness of point-of-care C-reactive protein testing to inform antibiotic prescribing decisions. Br. J. Gen. Pract. 2013, 63, e465-e471. [CrossRef]

42. Llor, C.; Hernández, S.; Cots, J.M.; Bjerrum, L.; González, B.; García, G.; Alcántara, J.d.D.; Guerra, G.; Cid, M.; Gómez, M.; et al. [Physicians with access to point-of-care tests significantly reduce the antibiotic prescription for common cold]. Rev. Esp. Quimioter. 2013, 26, 12-20.

43. Joshi, A.; Perin, D.P.; Gehle, A.; Nsiah-Kumi, P.A. Feasibility of using C-reactive protein for point-of-care testing. Technol. Health Care 2013, 21, 233-240.

44. Llor, C.; Cots, J.M.; López-Valcárcel, B.G.; Arranz, J.; García, G.; Ortega, J.; Gómez, M.; Guerra, G.; Monedero, M.J.; Alcántara, J.D.; et al. Interventions to reduce antibiotic prescription for lower respiratory tract infections: Happy Audit study. Eur. Respir. J. 2012, 40, 436-441. [CrossRef]

45. Llor, C.; Bjerrum, L.; Arranz, J.; García, G.; Cots, J.M.; González López-Valcárcel, B.; Monedero, M.J.; Gómez, M.; Ortega, J.; Guerra, G.; et al. C-reactive protein testing in patients with acute rhinosinusitis leads to a reduction in antibiotic use. Fam. Pract. 2012, 29, 653-658. [CrossRef]

46. Anthierens, S.; Tonkin-Crine, S.; Douglas, E.; Fernandez-Vandellos, P.; Krawczyk, J.; Llor, C.; Cals, J.W.L.; Francis, N.A.; Yardley, L.; Coenen, S.; et al. General practitioners' views on the acceptability and applicability of a web-based intervention to reduce antibiotic prescribing for acute cough in multiple European countries: A qualitative study prior to a randomised trial. BMC Fam. Pract. 2012, 13, 9. [CrossRef] [PubMed]

47. Kavanagh, K.E.; O'Shea, E.; Halloran, R.; Cantillon, P.; Murphy, A.W. A pilot study of the use of near-patient C-Reactive Protein testing in the treatment of adult respiratory tract infections in one Irish general practice. BMC Fam. Pract. 2011, 12, 93. [CrossRef] [PubMed]

48. Cals, J.W.L.; Ament, A.J.H.A.; Hood, K.; Butler, C.C.; Hopstaken, R.M.; Wassink, G.F.; Dinant, G.-J. C-reactive protein point of care testing and physician communication skills training for lower respiratory tract infections in general practice: Economic evaluation of a cluster randomized trial. J. Eval. Clin. Pract. 2011, 17, 1059-1069. [CrossRef] 
49. Llor, C.; Sierra, N.; Hernández, S.; Moragas, A.; Hernández, M.; Bayona, C.; Miravitlles, M. Impact of C-reactive protein testing on adherence to thrice-daily antibiotic regimens in patients with lower respiratory tract infection. Prim. Care Respir. J. 2010, 19, 358-362. [CrossRef] [PubMed]

50. Jakobsen, K.A.; Melbye, H.; Kelly, M.J.; Ceynowa, C.; Molstad, S.; Hood, K.; Butler, C.C. Influence of CRP testing and clinical findings on antibiotic prescribing in adults presenting with acute cough in primary care. Scand. J. Prim. Health Care 2010, 28, 229-236. [CrossRef]

51. Cals, J.W.L.; Chappin, F.H.F.; Hopstaken, R.M.; van Leeuwen, M.E.; Hood, K.; Butler, C.C.; Dinant, G.-J. C-reactive protein point-of-care testing for lower respiratory tract infections: A qualitative evaluation of experiences by GPs. Fam. Pract. 2010, 27, 212-218. [CrossRef]

52. Rausch, S.; Flammang, M.; Haas, N.; Stein, R.; Tabouring, P.; Delvigne, S.; Holper, D.; Jentges, C.; Pieger, M.; Lieunard, C.; et al. C-reactive protein to initiate or withhold antibiotics in acute respiratory tract infections in adults, in primary care: Review. Bull. Soc. Sci. Med. Grand. Duche Luxemb. 2009, 79-87.

53. Cals, J.W.L.; Butler, C.C.; Dinant, G.J. ‘Experience talks': Physician prioritisation of contrasting interventions to optimise management of acute cough in general practice. Implement. Sci. 2009, 4, 6. [CrossRef]

54. Cohen, R.; Lécuyer, A.; Wollner, C.; Deberdt, P.; Thollot, F.; Henriquet, V.; de La Rocque, F. [Evaluation of impact of CRP rapid test in management of febrile children in ambulatory pediatric practice]. Arch Pediatr. 2008, 15, 1126-1132. [CrossRef]

55. Muszyńska, A.; Steciwko, A.; Horst-Sikorska, W.; Siebert, J.; Mastalerz-Migas, A.; Wawrzyniak, A.; Nitsch-Osuch, A.; Zycińska, K.; Babińska, Z.; Pokorna-Kałwak, D.; et al. Usefulness of rapid CRP tests (NycoCard II ${ }^{\circledR}$ CRP) in everyday work of a family doctor, in the aspect of rationalization of indications for antibiotic therapy in acute infections. Fam. Med. Prim. Care Rev. 2007, 9, 998-1006.

56. Briel, M.; Young, J.; Tschudi, P.; Hersberger, K.E.; Hugenschmidt, C.; Langewitz, W.; Bucher, H.C. Prevalence and influence of diagnostic tests for acute respiratory tract infections in primary care. Swiss Med. Wkly. 2006, 136, 248-253. [PubMed]

57. Bjerrum, L.; Gahrn-Hansen, B.; Munck, A.P. [General practitioners who use CRP have a lower antibiotic prescribing rate to patients with sinusitis - secondary publication]. Ugeskr Laeger. 2005, 167, 2775-2777. [PubMed]

58. Bjerrum, L.; Gahrn-Hansen, B.; Munck, A.P. C-reactive protein measurement in general practice may lead to lower antibiotic prescribing for sinusitis. Br. J. Gen. Pract. 2004, 54, 659-662.

59. Fagan, M.S. Can the use of antibiotic in the treatment of acute bronchitis be reduced? [Kan bruk av antibiotika ved akutt bronkitt reduseres?]. Tidsskr Nor Laegeforen. 2001, 121, 455-458. [PubMed]

60. Dahler-Eriksen, B.S.; Lauritzen, T.; Lassen, J.F.; Lund, E.D.; Brandslund, I. Near-patient test for C-reactive protein in general practice: Assessment of clinical, organizational, and economic outcomes. Clin. Chem. 1999, 45, 478-485. [CrossRef] [PubMed]

61. Schot, M.J.; Van den Bruel, A.; Broekhuizen, B.D.; Cals, J.W.; Noteboom, E.A.; Balemans, W.; Hopstaken, R.M.; van Delft, S.; de Wit, N.J.; Verheij, T.J. Point-of-care C-reactive protein to assist in primary care management of children with suspected non-serious lower respiratory tract infection: A randomised controlled trial. BJGP Open 2018, 2, bjgpopen18X101600. [CrossRef]

62. Verbakel, J.Y.; Lemiengre, M.B.; De Burghgraeve, T.; De Sutter, A.; Aertgeerts, B.; Shinkins, B.; Perera, R.; Mant, D.; Van den Bruel, A.; Buntinx, F. Should all acutely ill children in primary care be tested with point-of-care CRP: A cluster randomised trial. BMC Med. 2016, 14, 131. [CrossRef]

63. Van den Bruel, A.; Jones, C.; Thompson, M.; Mant, D. C-reactive protein point-of-care testing in acutely ill children: A mixed methods study in primary care. Arch. Dis. Child 2016, 101, 382-385. [CrossRef]

64. Rebnord, I.K.; Sandvik, H.; Mjelle, A.B.; Hunskaar, S. Out-of-hours antibiotic prescription after screening with $C$ reactive protein: A randomised controlled study. BMJ Open 2016, 6, e011231. [CrossRef]

65. Do, N.T.; Ta, N.T.; Tran, N.T.; Than, H.M.; Vu, B.T.; Hoang, L.B.; van Doorn, H.R.; Vu, D.T.; Cals, J.W.; Chandna, A.; et al. Point-of-care C-reactive protein testing to reduce inappropriate use of antibiotics for non-severe acute respiratory infections in Vietnamese primary health care: A randomised controlled trial. Lancet Glob Health 2016, 4, e633-e641. [CrossRef]

66. Andreeva, E.; Melbye, H. Usefulness of C-reactive protein testing in acute cough/respiratory tract infection: An open cluster-randomized clinical trial with C-reactive protein testing in the intervention group. BMC Fam. Pract. 2014, 15, 80. [CrossRef] [PubMed] 
67. Little, P.; Stuart, B.; Francis, N.; Douglas, E.; Tonkin-Crine, S.; Anthierens, S.; Cals, J.W.; Melbye, H.; Santer, M.; Moore, M.; et al. Effects of internet-based training on antibiotic prescribing rates for acute respiratory-tract infections: A multinational, cluster, randomised, factorial, controlled trial. Lancet 2013, 382, 1175-1182. [CrossRef]

68. Gonzales, R.; Aagaard, E.M.; Camargo, C.A., Jr.; Ma, O.J.; Plautz, M.; Maselli, J.H.; McCulloch, C.E.; Levin, S.K.; Metlay, J.P. C-reactive protein testing does not decrease antibiotic use for acute cough illness when compared to a clinical algorithm. J. Emerg. Med. 2011, 41, 1-7. [CrossRef]

69. Cals, J.W.; Schot, M.J.; de Jong, S.A.; Dinant, G.J.; Hopstaken, R.M. Point-of-care C-reactive protein testing and antibiotic prescribing for respiratory tract infections: A randomized controlled trial. Ann. Fam. Med. 2010, 8, 124-133. [CrossRef]

70. Cals, J.W.; Butler, C.C.; Hopstaken, R.M.; Hood, K.; Dinant, G.J. Effect of point of care testing for C reactive protein and training in communication skills on antibiotic use in lower respiratory tract infections: Cluster randomised trial. BMJ 2009, 338, b1374. [CrossRef]

71. Takemura, Y.; Ebisawa, K.; Kakoi, H.; Saitoh, H.; Kure, H.; Ishida, H.; Kure, M. Antibiotic selection patterns in acutely febrile new outpatients with or without immediate testing for $\mathrm{C}$ reactive protein and leucocyte count. J. Clin. Pathol. 2005, 58, 729-733. [CrossRef] [PubMed]

72. Diederichsen, H.Z.; Skamling, M.; Diederichsen, A.; Grinsted, P.; Antonsen, S.; Petersen, P.H.; Munck, A.P.; Kragstrup, J. Randomised controlled trial of CRP rapid test as a guide to treatment of respiratory infections in general practice. Scand. J. Prim. Health Care 2000, 18, 39-43.

73. Melbye, H.; Aaraas, I.; Fleten, N.; Kolstrup, N.; Mikalsen, J.I. [The value of C-reactive protein testing in suspected lower respiratory tract infections. A study from general practice on the effect of a rapid test on antibiotic research and course of the disease in adults]. Tidsskr Nor Laegeforen. 1995, 115, 1610-1615.

74. Lemiengre, M.B.; Verbakel, J.Y.; Colman, R.; Van Roy, K.; De Burghgraeve, T.; Buntinx, F.; Aertgeerts, B.; De Baets, F.; De Sutter, A. Point-of-care CRP matters: Normal CRP levels reduce immediate antibiotic prescribing for acutely ill children in primary care: A cluster randomized controlled trial. Scand. J. Prim. Health Care 2018, 36, 423-436. [CrossRef]

75. Lemiengre, M.B.; Verbakel, J.Y.; Colman, R.; De Burghgraeve, T.; Buntinx, F.; Aertgeerts, B.; De Baets, F.; De Sutter, A. Reducing inappropriate antibiotic prescribing for children in primary care: A cluster randomised controlled trial of two interventions. Br. J. Gen. Pract. 2018, 68, e204-e210. [CrossRef]

76. Lemiengre, M.B.; Verbakel, J.Y.; De Burghgraeve, T.; Aertgeerts, B.; De Baets, F.; Buntinx, F.; De Sutter, A. Optimizing antibiotic prescribing for acutely ill children in primary care (ERNIE2 study protocol, part B): A cluster randomized, factorial controlled trial evaluating the effect of a point-of-care C-reactive protein test and a brief intervention combined with written safety net advice. BMC Pediatr. 2014, 14, 246.

77. Rebnord, I.K.; Sandvik, H.; Mjelle, A.B.; Hunskaar, S. Factors predicting antibiotic prescription and referral to hospital for children with respiratory symptoms: Secondary analysis of a randomised controlled study at out-of-hours services in primary care. BMJ Open 2017, 7, e012992. [CrossRef] [PubMed]

78. Little, P.; Stuart, B.; Francis, N.; Douglas, E.; Tonkin-Crine, S.; Anthierens, S.; Cals, J.W.L.; Melbye, H.; Santer, M.; Moore, M.; et al. Antibiotic Prescribing for Acute Respiratory Tract Infections 12 Months After Communication and CRP Training: A Randomized Trial. Ann. Fam. Med. 2019, 17, 125-132. [CrossRef]

79. Yardley, L.; Douglas, E.; Anthierens, S.; Tonkin-Crine, S.; O’Reilly, G.; Stuart, B.; Geraghty, A.W.; Arden-Close, E.; van der Velden, A.W.; Goosens, H.; et al. Evaluation of a web-based intervention to reduce antibiotic prescribing for LRTI in six European countries: Quantitative process analysis of the GRACE/INTRO randomised controlled trial. Implement. Sci. 2013, 8, 134. [CrossRef]

80. Cals, J.W.; de Bock, L.; Beckers, P.J.; Francis, N.A.; Hopstaken, R.M.; Hood, K.; de Bont, E.G.; Butler, C.C.; Dinant, G.J. Enhanced communication skills and C-reactive protein point-of-care testing for respiratory tract infection: 3.5-year follow-up of a cluster randomized trial. Ann. Fam. Med. 2013, 11, 157-164. [CrossRef] [PubMed]

81. Cals, J.W.; Hopstaken, R.M.; Butler, C.C.; Hood, K.; Severens, J.L.; Dinant, G.J. Improving management of patients with acute cough by $\mathrm{C}$-reactive protein point of care testing and communication training (IMPAC3T): Study protocol of a cluster randomised controlled trial. BMC Fam. Pract. 2007, 8, 15. [CrossRef]

82. Diederichsen, H.Z.; Skamling, M.; Diederichsen, A.; Grinsted, P.; Antonsen, S.; Petersen, P.H.; Munck, A.P.; Kragstrup, J. [A randomized controlled trial of the use of CRP rapid test as a guide to treatment of respiratory infections in general practice]. Ugeskr Laeger. 2001, 163, 3784-3787. 
83. VALUE-Dx.eu [Internet]. Platform Randomised Controlled Trial of Point of Care Diagnostics for Enhancing the Quality of aNtibiotic Prescribing for Community Acquired Acute Respiratory Tract Infection (CA-ARTI) in Ambulatory Care in Europe-The PRUDENCE Trial. Available online: https://value-dx.eu/index.php/ work-package-4/ (accessed on 8 September 2020).

84. ClinicalTrials.gov [Internet]. Identifier: NCT04470518. Impact of Clinical Guidance $\mathcal{E}$ Point-of-care CRP in Children: The ARON Project (ARON); National Library of Medicine: Bethesda, MD, USA, 2020. Available online: https://clinicaltrials.gov/ct2/show/NCT04470518 (accessed on 8 September 2020).

85. Grol, R.; Dalhuijsen, J.; Thomas, S.; Veld, C.i.t.; Rutten, G.; Mokkink, H. Attributes of clinical guidelines that influence use of guidelines in general practice: Observational study. BMJ 1998, 317, 858-861. [CrossRef]

86. Jones, C.H.; Howick, J.; Roberts, N.W.; Price, C.P.; Heneghan, C.; Plüddemann, A.; Thompson, M. Primary care clinicians' attitudes towards point-of-care blood testing: A systematic review of qualitative studies. BMC Fam. Pract. 2013, 14, 117. [CrossRef]

87. Spurling, G.K.; Del Mar, C.B.; Dooley, L.; Foxlee, R.; Farley, R. Delayed antibiotic prescriptions for respiratory infections. Cochrane Database Syst. Rev. 2017, 9, CD004417. [CrossRef]

88. Van Vugt, S.F.; Broekhuizen, B.D.; Lammens, C.; Zuithoff, N.P.; de Jong, P.A.; Coenen, S.; Ieven, M.; Butler, C.C.; Goossens, H.; Little, P.; et al. Use of serum $\mathrm{C}$ reactive protein and procalcitonin concentrations in addition to symptoms and signs to predict pneumonia in patients presenting to primary care with acute cough: Diagnostic study. BMJ 2013, 346, f2450. [CrossRef] [PubMed]

89. Huang, Y.; Chen, R.; Wu, T.; Wei, X.; Guo, A. Association between point-of-care CRP testing and antibiotic prescribing in respiratory tract infections: A systematic review and meta-analysis of primary care studies. Br. J. Gen. Pract. 2013, 63, e787-e794. [CrossRef] [PubMed]

90. Engel, M.F.; Paling, F.P.; Hoepelman, A.I.; van der Meer, V.; Oosterheert, J.J. Evaluating the evidence for the implementation of C-reactive protein measurement in adult patients with suspected lower respiratory tract infection in primary care: A systematic review. Fam. Pract. 2012, 29, 383-393. [CrossRef]

91. Martinez-Gonzalez, N.A.; Coenen, S.; Plate, A.; Colliers, A.; Rosemann, T.; Senn, O.; Neuner-Jehle, S. The impact of interventions to improve the quality of prescribing and use of antibiotics in primary care patients with respiratory tract infections: A systematic review protocol. BMJ Open 2017, 7, e016253. [CrossRef]

92. Liberati, A.; Altman, D.G.; Tetzlaff, J.; Mulrow, C.; Gotzsche, P.C.; Ioannidis, J.P.; Clarke, M.; Devereaux, P.J.; Kleijnen, J.; Moher, D. The PRISMA statement for reporting systematic reviews and meta-analyses of studies that evaluate health care interventions: Explanation and elaboration. PLoS Med. 2009, 6, e1000100. [CrossRef]

93. Egger, M.; Smith, G.D.; Altman, D.G. Principles of and Procedures for Systematic Reviews. In Systematic Reviews in Health Care; BMJ Publishing Group: London, UK, 2008; pp. $23-42$.

94. Higgins, J.P.T.; Green S, E. Cochrane Handbook for Systematic Reviews of Interventions; Version 5.1.0 [updated March 2011]; The Cochrane Collaboration: London, UK, 2011.

95. Centre for Research in Evidence Based Practice (CREBP). Faculty of Health Sciences and Medicine. In Systematic Reviews Practical Manual; Bond University: Gold Coast, Australia, 2014.

96. Juni, P.; Witschi, A.; Bloch, R.; Egger, M. The hazards of scoring the quality of clinical trials for meta-analysis. JAMA 1999, 282, 1054-1060. [CrossRef] [PubMed]

97. Review Manager (RevMan); Version 5.4; The Nordic Cochrane Centre: Copenhagen, Denmark; The Cochrane Collaboration: London, UK, 2012.

98. Higgins, J.P.; Thompson, S.G. Quantifying heterogeneity in a meta-analysis. Stat. Med. 2002, 21, 1539-1558. [CrossRef]

99. Egger, M.; Davey Smith, G.; Schneider, M.; Minder, C. Bias in meta-analysis detected by a simple, graphical test. BMJ 1997, 315, 629-634. [CrossRef] [PubMed]

100. Li, G.; Lip, G.Y.H.; Marcucci, M.; Thabane, L.; Tian, J.; Levine, M.A. The number needed to treat for net effect (NNTnet) as a metric for measuring combined benefits and harms. J. Clin. Epidemiol. 2020, 125, 100-107. [CrossRef]

(C) 2020 by the authors. Licensee MDPI, Basel, Switzerland. This article is an open access article distributed under the terms and conditions of the Creative Commons Attribution (CC BY) license (http://creativecommons.org/licenses/by/4.0/). 